\title{
Remotely Sensed Hydroclimatic Variability for Water Security in an Agricultural Basin
}

\author{
Ashish Kondal \\ West Virginia University, ak0048@mix.wvu.edu
}

Follow this and additional works at: https://researchrepository.wvu.edu/etd

Part of the Civil Engineering Commons, and the Environmental Engineering Commons

\section{Recommended Citation}

Kondal, Ashish, "Remotely Sensed Hydroclimatic Variability for Water Security in an Agricultural Basin" (2018). Graduate Theses, Dissertations, and Problem Reports. 3739.

https://researchrepository.wvu.edu/etd/3739

This Thesis is protected by copyright and/or related rights. It has been brought to you by the The Research Repository @ WVU with permission from the rights-holder(s). You are free to use this Thesis in any way that is permitted by the copyright and related rights legislation that applies to your use. For other uses you must obtain permission from the rights-holder(s) directly, unless additional rights are indicated by a Creative Commons license in the record and/ or on the work itself. This Thesis has been accepted for inclusion in WVU Graduate Theses, Dissertations, and Problem Reports collection by an authorized administrator of The Research Repository @ WVU. For more information, please contact researchrepository@mail.wvu.edu. 


\section{REMOTELY SENSED HYDROCLIMATIC VARIABILITY FOR WATER SECURITY IN AN AGRICULTURAL BASIN}

\section{Ashish Kondal}

Thesis submitted to the College of Engineering and Mineral Resources at West Virginia University in partial fulfillment of the requirements for the Degree of

Master of Science

in

Civil and Environmental Engineering

Antarpreet Jutla, Ph.D., Chair

Lian-Shin Lin, Ph.D.

Timothy Andrew Warner, Ph.D.

\section{Department of Civil and Environmental Engineering}

\section{Morgantown, West Virginia \\ 2018}

Keywords: Remote Sensing, Indus Basin, Groundwater, Hydroclimatic Variability Copyright 2018 Ashish Kondal 


\title{
ABSTRACT \\ REMOTELY SENSED HYDROCLIMATIC VARIABILITY FOR WATER SECURITY IN AN AGRICULTURAL BASIN
}

\begin{abstract}
Ashish Kondal
The Indus Basin has supported agricultural practices since the Harappan civilization (3000-1500 BC). Abundance of water has always supported agriculture in the region and built the Indus Basin as one of the major agriculture based economies of the world. The obvious dependency of agriculture on weather and the vagaries of climate emphasizes the necessity of a comprehensive hydro-climate study of the region. The role of climate change in the Indus Basin has always been a contentious issue. Groundwater depletion is evident in the region, and its steady and alarmingly declining rate has brought concerns for the future of agriculture in the Indus Basin.

In this study, spatial and temporal trends of the hydro-climatic parameters; precipitation, air temperature, and snow cover, were determined to address changes in such processes. No statistically significant changes were observed in hydro-climatological processes that could lead to agriculture failure, but recently the prospect of permanent desertification has been lingering over some parts of the Indus Basin. The origin of this situation lie in unmonitored and extensive tapping of historically untouched groundwater resources for irrigation purposes. Punjab, a state in NorthWest India, is considered to be fundamental to India's food security was chosen to assess the groundwater depletion. It is found out that, with the current rate of groundwater depletion and with paddy as a mainstream crop, total groundwater depletion is inevitable in coming decades. We have
\end{abstract}


generated a series of groundwater scenarios using aquifer data to challenge the notion of paddy dominant cropping system and have produced timelines to identify the time when the water required for paddy cultivation has or will surpass the total volume of groundwater that can be provided by certain aquifer over that specific area. This study clearly indicates that the exponential increase in paddy cultivation has put the groundwater resources under stress and it is just a matter of time that what has been happening in some part of Indus Basin becomes the dominant fate of the region. 


\section{ACKNOWLEDGEMENTS}

I would first like to express my sincere gratitude to my thesis advisor, Dr. Antarpreet Jutla for his continued support and encouragement throughout my master degree. I am extremely thankful to him for his scholarly advice, patience, enthusiasm and for giving me the freedom to explore new things.

I am thankful to my committee members, Dr. Lian-Shin Lin and Dr. Timothy Andrew Warner for their guidance and suggestions throughout my course and thesis work, that has prepared me to conduct the research.

I would also like to extend my gratitude to my fellow lab members; Dr. Rakibul Khan and Moiz Usmani for their guidance and sharing knowledge in every step of researching and writing thesis. I also like to give special thanks to my friends, Amit Raizada and Rishabh Soni for their constant cheering up and moral support through my all ups and downs.

I can't thank my parents and my brother enough for their unconditional love and for always being there for me, whenever I needed them. This accomplishment would not have been possible without their support that has been my biggest strength throughout my life. Finally, I thank my creator, The Almighty for everything in my life. 


\section{TABLE OF CONTENTS}

Page No.

ABSTRACT.

ii

ACKNOWLEDGEMENTS

iv

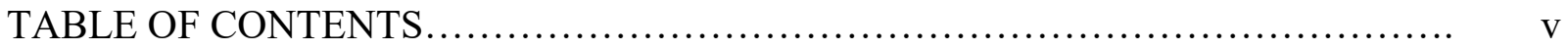

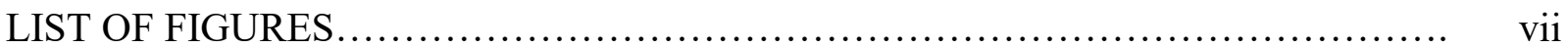

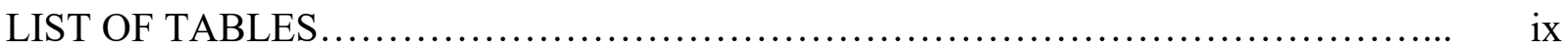

CHAPTER $1 \quad$ INTRODUCTION....................................... 1

CHAPTER $2 \quad$ STUDY AREA......................................... 4

2.1 Indus Basin....................................... 4

2.2 Punjab........................................ 5

CHAPTER $3 \quad$ LITERATURE REVIEW ................................ 7

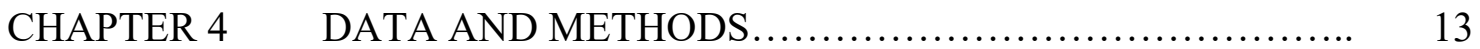

CHAPTER $5 \quad$ RESULTS AND DISCUSSION.......................... 17

5.1 MERRA-2 Precipitation.......................... 17

5.1.1 Convective Precipitation.............. 17

5.1.2 Large Scale Precipitation.............. 23

5.1.3 Snowfall............................. 29

5.1.4 Total Precipitation.................... 31

5.2 PREC/L Precipitation............................... 36

5.3 MERRA-2 Air Temperature....................... 39

5.4 MODIS Snow Cover.............................. 42

5.5 Combined Overview of Hydro-climatic Parameters..... $\quad 44$ 
5.6 Current and Prospective Status of Groundwater

in Punjab........................................................ 44

CHAPTER 6 SUMMARY AND CONCLUSION............................ 49

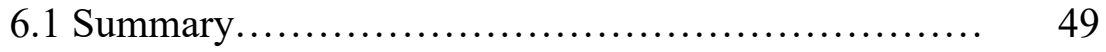

6.2 What Could be the Ideal Agricultural

Scenario in the Indus Basin? ....................................... 50

6.3 Future Work..................................... 51

6.3.1 Scope for Future Exploratory Studies on Hydro-climatic Parameters........... 51

6.3.2 Trade-off Between Food Security and Water Security......................... 51

CHAPTER $7 \quad$ BIBLIOGRAPHY ...................................... 53

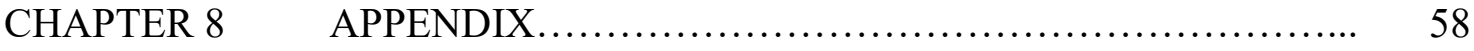




\section{LIST OF FIGURES}

Page No.

Figure 1. Extent of the Indus Basin and the Punjab............................. 6

Figure 2. Spatial trend map of annual convective precipitation.................... 17

Figure 3. Spatial trend map of seasonal convective precipitation.................... 20

Figure 4A. Spatial trend map of monthly convective precipitation

(JAN-FEB-MAR-APR-MAY-JUNE)....... 21

Figure 4B. Spatial trend map of monthly convective precipitation

(JULY-AUG-SEPT-OCT-NOV-DEC)......

Figure 5. Spatial trend map of annual large scale precipitation..................... 23

Figure 6. Spatial trend map of seasonal large scale precipitation..................... 26

Figure 7A. Spatial trend map of monthly large scale precipitation

(JAN-FEB-MAR-APR-MAY-JUNE)......

Figure 7B. Spatial trend map of monthly large scale precipitation

(JULY-AUG-SEPT-OCT-NOV-DEC)......

Figure 8. Spatial trend map of annual snowfall

Figure 9. Spatial trend map of annual total precipitation........................ 31

Figure 10. Spatial trend map of seasonal total precipitation....................... 33

Figure 11A. Spatial trend map of monthly total precipitation

(JAN-FEB-MAR-APR-MAY-JUNE)......

Figure 11B. Spatial trend map of monthly total precipitation

(JULY-AUG-SEPT-OCT-NOV-DEC)......

Figure 12. Spatial trend map of PREC/L annual precipitation

Figure 13. Spatial trend map of PREC/L seasonal precipitation

Figure 14. Spatial trend map of annual air temperature at $2 \mathrm{~m}$. 
Figure 15. Spatial trend map of annual air temperature at $10 \mathrm{~m} \ldots \ldots \ldots \ldots \ldots \ldots \ldots \ldots . \ldots . \ldots . \ldots . \ldots$

Figure 16. Timeline for Aquifer I with respect to Paddy Water Requirement............ 46

Figure 17. Timeline for Aquifer II with respect to Paddy Water Requirement............ 47

Figure 18. Timeline for Aquifer III with respect to Paddy Water Requirement.......... 48

Figure 19. Spatial trend map of seasonal snowfall............................. 58

Figure 20A. Spatial trend map of monthly snowfall

(JAN-FEB-MAR-APR-MAY-JUNE)......

Figure 20B. Spatial trend map of monthly snowfall

(JULY-AUG-SEPT-OCT-NOV-DEC)......

Figure 21A. Spatial trend map of PREC/L monthly precipitation

(JAN-FEB-MAR-APR-MAY-JUNE)......

Figure 21B. Spatial trend map of PREC/L monthly precipitation

(JULY-AUG-SEPT-OCT-NOV-DEC).....

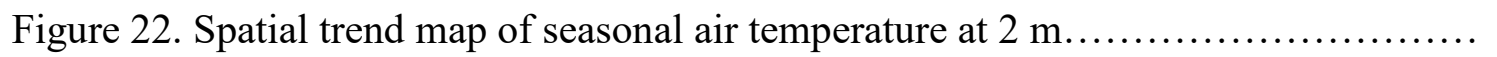

Figure 23A. Spatial trend map of monthly air temperature at $2 \mathrm{~m}$

(JAN-FEB-MAR-APR-MAY-JUNE) $\ldots . . .$.

Figure 23B. Spatial trend map of monthly air temperature at $2 \mathrm{~m}$

(JULY-AUG-SEPT-OCT-NOV-DEC)......

Figure 24. Spatial trend map of seasonal air temperature at $10 \mathrm{~m}$

Figure 25A. Spatial trend map of monthly air temperature at $10 \mathrm{~m}$

(JAN-FEB-MAR-APR-MAY-JUNE).......

Figure 25B. Spatial trend map of monthly air temperature at $10 \mathrm{~m}$

(JULY-AUG-SEPT-OCT-NOV-DEC)...... 


\section{LIST OF TABLES}

Page No.

Table 1. District-wise summary of aquifer characteristics of Punjab................. 15

Table 2. Monthly, seasonal and annual trends of spatially averaged MERRA-2

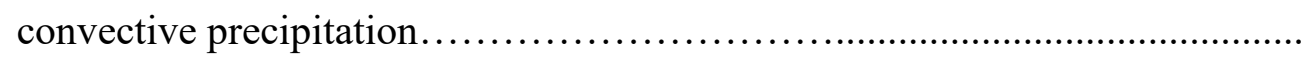

Table 3. Monthly, seasonal and annual trends of spatially averaged MERRA-2

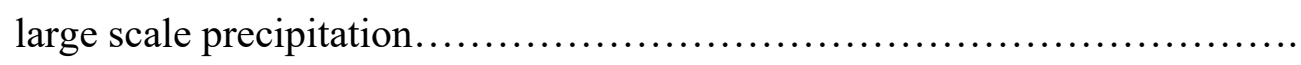

Table 4. Monthly, seasonal and annual trends of spatially averaged MERRA-2

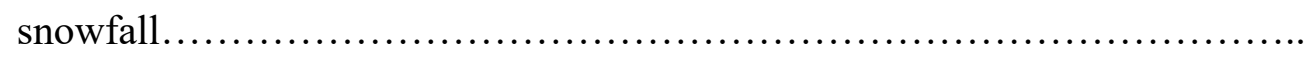

Table 5. Monthly, seasonal and annual trends of spatially averaged MERRA-2

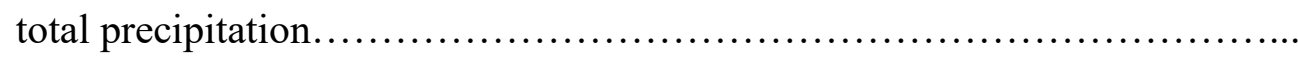

Table 6. Monthly, seasonal and annual trends of spatially averaged PREC/L

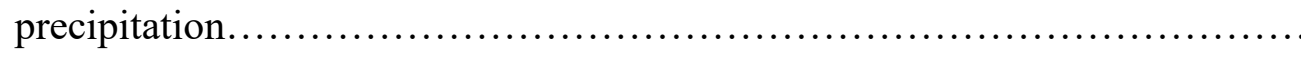

Table 7. Monthly, seasonal and annual trends of spatially averaged MERRA-2

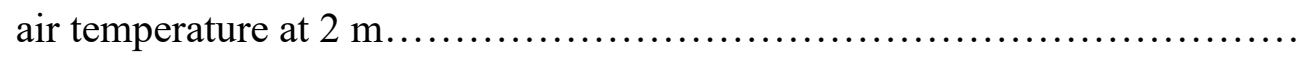

Table 8. Monthly, seasonal and annual trends of spatially averaged MERRA-2

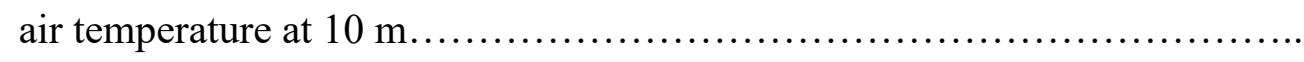

Table 9. Monthly, seasonal and annual trends of spatially averaged MODIS snow cover extent. 


\section{CHAPTER 1: INTRODUCTION}

The Indus Basin is one of the largest river basins in Asia extending between the Hindukush - Karakoram - Himalaya (HKH) Mountains range and the Tibetan Plateau. The Indus River is also one of the largest rivers in Asia, collecting water from many tributaries, many of which are major rivers in themselves. The Indus Basin has a history of prosperous civilization with agriculture as its underpinning. Abundance of water resources had always supported agriculture over the region and built the Indus Basin as an empire with an agriculture based economy. In addition to providing most of Pakistan's arable land, it also includes India's most valuable arable land in term of food security, which make this basin very important in agro-economic terms. In Pakistan alone, agriculture supports approximately $75 \%$ of the population, provides employment to $44 \%$ of the labor force and accounts for more than $60 \%$ of foreign exchange earnings (Qureshi, 2011).

The Indus Basin experiences all types of precipitation, but most of water comes from rain and snow. The extent of precipitation generally depends upon climatic factors, topographic factors, wind speed and wind orientation. Along with these factors, complex orographic barriers affect the magnitude, frequency and intensity of precipitation. Due to these insurmountable orographic characteristics of the Indus Basin, hydro-meteorological parameters vary spatially as well as temporally. Most prominent and influential effects of these orographic characteristics are on the precipitation in the Indus Basin. Rain is the most common form of precipitation in low elevation regions, where it directly contributes to runoff. Though, snow also occurs in low elevation region, but it melts faster than at high elevation regions and therefore more rapidly becomes part of the runoff. In contrast, precipitation occurs as snow in high elevation regions, where it initially is 
stored and then with time, melts and contributes to surface runoff and river flow (Archer, 2003). This runoff originated from snow or glacier melt is the main source of water to perennial rivers, which ultimately facilitate agriculture through vast canal network in the Indus Basin.

Climate change and its influence on water resources in the Indus Basin has always been a contentious issue, but discrepancies in climate studies have highlighted complications in the generally accepted view of climate over the region. It is widely known that the irrigation dependent agriculture is more prevalent in the Indus Basin than anywhere else in the world, around 80 percent of arable land is under irrigation in Pakistan alone. A rapid growth in population and thus increasing demands for food, with no new water supply, has put existing water resources under stress (Qureshi, 2011). Moreover, the lack of consensus on climate change has complicated and exacerbated this water stress, and further, causes a challenge to compete for water supply within different sectors of community especially for agriculture. The dependency of agriculture on weather is well known and the vagaries of climate can affect food production (Gadgil and Kumar, 2006), so it is very important to have a clear understanding of the regional climate system.

Agriculture can only flourish and be sustained through adequate water supply, required for crop growth and production. Both water scarcity as well as excess, can cause a loss in crop productivity and loss in crop yield (Gadgil and Kumar, 2006). Most of the cultivable area in the Indus Basin is under irrigation through well-connected canal networks (Yu et al., 2013) and only minority of the area is rain-fed, nevertheless, the direct importance of rainfall to agriculture cannot be understated or ignored. The variability of precipitation and its intensity, erratic rain events, and poor temporal and spatial distribution of rainfall, plays an important role in sustaining and safekeeping the standing crop. 
This study had two main objectives: -

1) To mitigate the ambiguity of climate change and its implications on water resources in the Indus Basin.

2) To explore groundwater decline in the Punjab region of India. The Punjab was selected for its unique contribution in achieving and ensuring food security in India during the Green Revolution. The timelines of groundwater storage depletion are generated based on current groundwater depletion, recharge and current cropping practice (only paddy crop has been used, instead of full cropping rotation). These timelines identifies the time period, when the aquifer had or will have insufficient water to sustain paddy crop.

This study provides a clear insight on climate change over the Indus Basin along with highlighting the severity of groundwater depletion in the Punjab and illuminates the major factor that has caused and continuously exacerbated this situation. 


\section{CHAPTER 2: STUDY AREA}

\subsection{Indus Basin}

The Indus Basin covers about 11,54,500 $\mathrm{km}^{2}$, spread over parts of Pakistan (47\%), India (39\%), Afghanistan (6\%) and China (8\%) (Dahri et al., 2016) (Figure 1). Major tributaries of the Indus River are the Jhelum, the Chenab, the Ravi, the Beas and the Sutlej from east and the Kabul, the Swat, and the Kurd from west. Millions of people depends upon the river flow of the Upper Indus Basin (UIB) for food security and for their livelihoods. To ensure the wellbeing of Pakistan and Northern India, its water resources are of the utmost importance, for supporting local incomes and food nutrition through irrigated agriculture and the electricity supplied through hydropower (Forsyethe et al., 2012). The Indus Basin Irrigation System is the largest irrigation system in the world, with Pakistan accounting for $60.9 \%$ of the irrigated land and India $37.2 \%$ (Laghari et al., 2012). Archer et al. (2010) conducted a comprehensive study on water resources management of the Indus Basin, that identified the importance of these water resources for limiting food insecurity and electricity load-shedding in Pakistan. However, the upstream areas of UIB, which provides maximum water for the basin, lacks infrastructure in comparison to downstream areas, thus communities residing in downstream areas get much greater benefits than the upstream communities (Forsyethe et al., 2012). To attain equality between downstream and upstream communities across the Indus basin, it is important to monitor the driving forces which causes these anomalies. Other than snow and glacier melt, precipitation is the main driving force, which affects the river flow and thus, consequently affects agriculture and other life sustaining activities over the region. 


\subsection{Punjab}

Punjab state, located in northeastern part of the Indus Basin, extends from $29.30^{\circ} \mathrm{N}$ to $32.32^{\circ} \mathrm{N}$ and $73.55^{\circ} \mathrm{E}$ to $76.5^{\circ} \mathrm{E}$. It shares boundaries with four states: Jammu \& Kashmir in the north-east, Himachal Pradesh in the east, Haryana and Rajasthan in the south and one international boundary with Pakistan to the west (Chopra and Krishan, 2014) (Figure 1). Punjab is predominantly an agricultural state that is intensively engaged in irrigation-facilitated agriculture, with $98 \%$ of the net area sown under irrigation and $80 \%$ of the population is economically involved in agricultural practices. It has the highest percentage of irrigated land in comparison to the total cultivable land available in India (Chopra and Krishan, 2014; Grant, 2013). Groundwater resources has emerged as prime source of irrigation in the state. In recent times, groundwater use for irrigation has increased to $75 \%$ of the total irrigated area. This reliance on groundwater to satisfy demand has led to a steady decline in the water table (Grant, 2013).

In Punjab, the cropping season is categorized as rabi (mid-October to mid-April) and kharif seasons (mid-April to mid-October) (Ahmad et al., 2009). Rabi crops include wheat, pulses, oilseeds and fodder that are grown in September, October and November and harvested in March, April and May. Kharif season includes crops such as cotton, maize, rice, sorghum, vegetables and fodder which are grown in April, May and June and harvested in October and November (Bastiaanssen et al., 2002). Rabi crops requires comparatively lower temperature and lower rainfall than kharif crops during sowing period. Sowing and harvesting time of both rabi and kharif crops varies with different climatic conditions, cropping patterns, crop varieties, and other agricultural practices as well as the region (PAU, Package of Practices for Kharif Crops of Punjab, 2007; PAU, Package of Practices for Rabi Crops of Punjab, 2007-08). 


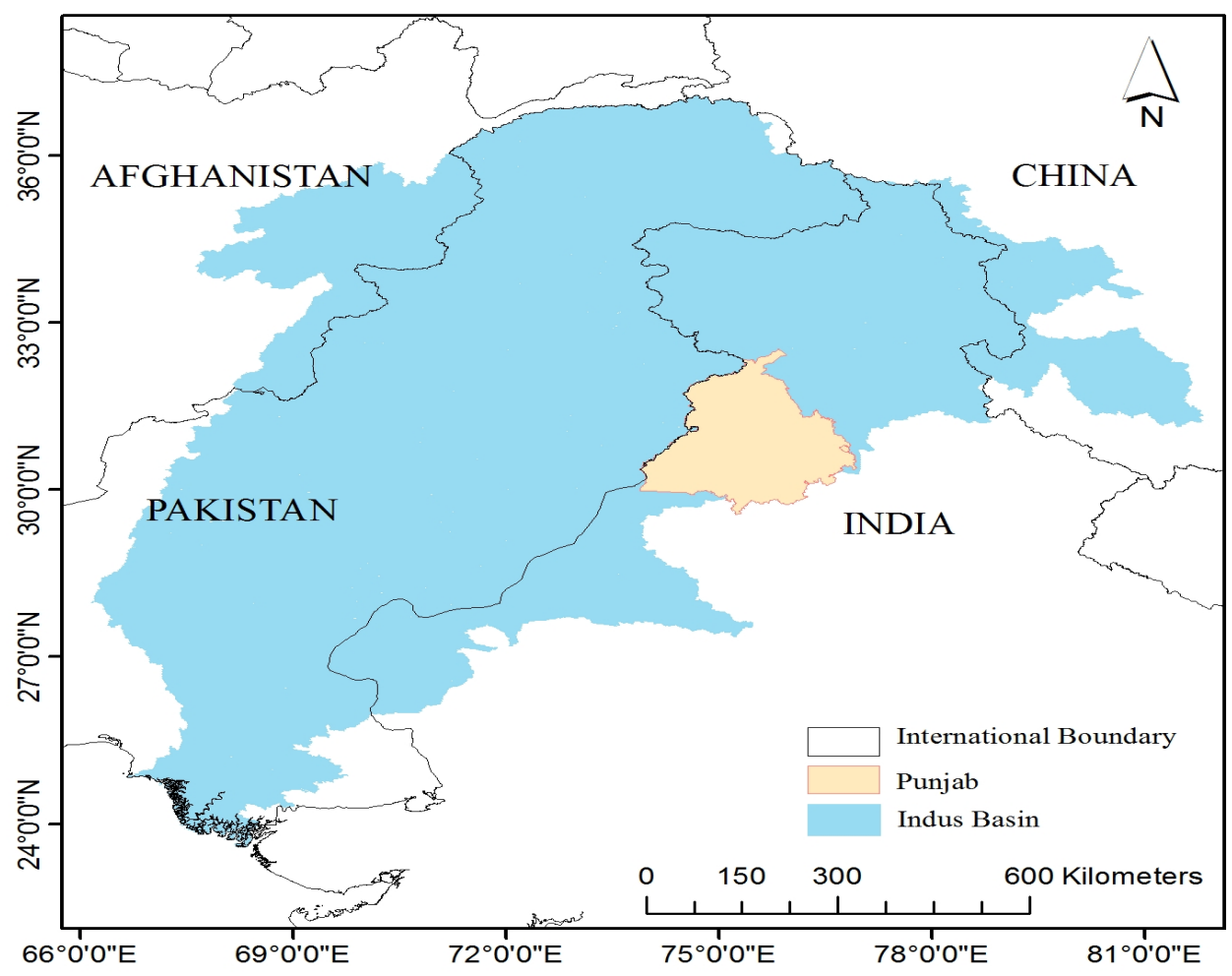

Figure 1. Extent of the Indus Basin and the Punjab

The prime motive for choosing the Punjab state for assessing the prospect of agriculture based on groundwater extraction in coming years, was due to its deep historical linkages in ensuring the food security of India. The concern for eliminating food insecurity in PostIndependence India led to a nationwide campaign for growing more crops. Punjab played a vital role in achieving and sustaining nationwide food security, and as a result it is called the "breadbasket of India" \& "granary of India". During the Green Revolution, introduction of cash crops such as paddy (rice) into the cropping system acted as a catalyst for ensuring food security and economic prosperity. Till 2000, 71 percent of cropped area was under rice-wheat cultivation (Singh, 2002) and it has been increasing 3.6 times since 1960. In addition, $80 \%$ of water resources has been used for agricultural production (Kaur et al., 2008). A severe issue of water scarcity now plagues Punjab and neighboring states due to excessive groundwater withdrawal. 


\section{CHAPTER 3: LITERATURE REVIEW}

The Indus Basin receives rainfall from two different sources, western winds disturbances and the south-eastern monsoon during summer. The Indus Basin receives a major portion of precipitation from westerly disturbances during winter and their contribution to annual precipitation decreases from north-west to south-east (Immerzeel et al., 2015). In contrast, precipitation from the monsoon decreases from the south-east to north-west (Sharif et al., 2013). Madhura et al. (2015) reported that most of annual precipitation in the Upper Indus Basin (UIB) occurs during winter, with summer precipitation only contributing one third to the annual precipitation (Young and Hewitt, 1990) and in context to regional influence, summer monsoon has a more prominent effect on the western Indus Basin i.e. sub basins of the Jhelum, the Chenab and the lower Indus River (Dahri et al., 2016). However, Wake (1989) suggested that the Indus Basin receives a major portion of annual precipitation during monsoon season at high altitudes.

Particularly in the Indus Basin, the effect of altitude on precipitation and amount of snow stored at high elevations is quite clear and well-studied. Dahri et al. (2016) conducted a study to analyze spatial distribution of precipitation and effects of altitude on precipitation in the Indus Basin. It found out that precipitation increases with elevation up to a certain height after which it declines and thus, confirming the presence of altitudinal variation in precipitation distribution over the Indus Basin. Dahri et al. (2016) also compared precipitation results derived from different datasets including TRMM and station gauge data and concluded that precipitation values derived from gridded datasets of different sources are prone to significant errors and therefore, these uncorrected datasets are not suited for hydrological modeling and water balance studies.

Archer (2003), and Fowler and Archer (2006) also mentioned altitudinal changes in precipitation along with defining the correlation between runoff and precipitation in the UIB. Both 
used station gauge data obtained from India Meteorological Department (IMD), Pakistan Meteorological Department (PMD) and Water and Power Development Authority (WAPDA). According to Archer (2003), at low elevation, precipitation mostly falls as rain and directly contributes to runoff and similarly, if snow falls on low elevation, it melts faster than at higher elevations and thus, become part of the runoff. In contrast, at high altitudes, precipitation occurs as snow, and due to less available heat energy, it gets stored. Thus, runoff from glacier melt and snow melt at high altitudes depends on the availability of heat energy rather than the occurrence of precipitation. It was also observed that the summer runoff, in the middle elevation basins of UIB, is correlated with winter precipitation, and negatively correlated with summer temperature and runoff because of high evaporative loss in the summer, thus limiting the volume of snow cover and resulting in low runoff. In contrast, this correlation does not hold well in the high altitude basins. In high altitude basins of UIB, summer river runoff is uncorrelated with winter precipitation but it has a positive correlation with summer mean temperature i.e. there is an increase in runoff with increase in summer mean temperature (Fowler and Archer, 2006).

Numerous studies have done in past, to determine the spatial and temporal characteristics of annual as well as seasonal precipitation in the Indus Basin, which have shown contrasting results. Singh and Sen Roy (2002) had found evidence of an increasing trend in winter precipitation and a simultaneously decreasing trend in summer precipitation. In contrast, Miehe (1992) observed decreasing winter precipitation over the previous 30 to 40 years.

A time series analysis performed on the Upper Indus Basin (UIB) by Archer and Fowler (2004) showed no significant long term trend in annual and seasonal precipitation. However, Palazzi et al. (2013) found a decrease in average precipitation towards the south east, but a significant increasing trend in average summer precipitation compared to average winter 
precipitation in the Himalaya region. From the recent study, Palazzi et al. (2015) suggested an increase in summer precipitation, but decrease in winter precipitation in Hindukush - Karakorum - Himalaya $(\mathrm{HKH})$ region.

Temporal variations in monthly, seasonal and annual precipitation were investigated over the western Himalayan region for the period 1857-2006 by Kumar and Jaswal (2016). A nonsignificant decreasing trend was found in annual and winter precipitation, and a non-significant increasing trend in post monsoon precipitation. However, monsoon and pre-monsoon precipitation showed a significant increasing trend for the entire period (Kumar and Jaswal, 2016).

To examine the variability in hydro-meteorological parameter such as air temperature and precipitation, Khattak et al. (2011) done a trend analysis in the Upper Indus Basin and yielded statistically significant findings on air temperature and precipitation. Twenty meteorological and eight hydrometric stations were considered to detect seasonal and regional trends in monthly mean minimum air temperature, maximum air temperature and monthly mean precipitation. Khattak et al. (2011) found that the significant decreasing trends of monthly mean minimum temperature were prevalent for $47 \%$ of the study sites at annual scale and $35 \%$ of the stations during spring and $76 \%$ during the summer season. In contrast, monthly mean maximum temperature showed a significantly increasing trend, especially during the winter months which had shown highest warming trend for $71 \%$ of the stations. However, the mean monthly precipitation showed no trend for the majority of the stations.

A similar temperature analysis was done by Fowler and Archer (2006) on the Upper Indus Basin using meteorological data from six trans-Himalayan stations for 1900 to 2000. It was concluded that in recent time from 1961 to 2000, there was a significant increase in diurnal temperature range for all seasons and at annual scale. In addition, summer mean temperature, 
summer minimum temperature, fall minimum temperature and annual minimum temperature showed a significant decreasing trend for the majority of considered stations. On the other hand, fall maximum temperature, winter maximum temperature, winter minimum temperature and annual maximum temperature showed a significant increasing trend (Fowler and Archer, 2006). These results were consistent with the results of Khattak et al. (2011).

In support to it, Bhutiyani et al. (2007) also studied trends in air temperature over northwest Himalayan region and identified a significant rise in annual temperature of about $1.6^{\circ} \mathrm{C}$ in the last century, mostly during the winter season. In addition, it was found that the minimum temperature raise at a much lower pace relative to maximum temperature and the increase in both maximum and minimum temperature has led to a significantly increasing trend in the diurnal temperature range.

In order to examine impact of climate change under different glacier coverage scenario and the estimation of water resources changes, a simulation based study was done by Akhtar et al. (2008) using PRECIS Regional Climate Model on present climate (1961-1990) and future SRES A2 climate scenarios (2071-2100) in Hindukush - Karakorum - Himalaya region and both temperature and precipitation were found to increase towards the end of the $21^{\text {st }}$ century.

In order to understand the trend in snow and ice storage, Immerzeel et al. (2010) used the DMT-1 GRACE gravity model along with a precipitation trend and found a positive trend of 0.19 $\pm 0.02 \mathrm{~m} \mathrm{year}^{-1}$ for the Indus Basin. A Normalized Melt Index (NMI) analysis was also done to quantify the importance of meltwater from the upstream area for the time period 2001 to 2007. Glacier and snow melt in upstream areas of the Indus Basin were found to generate a discharge that is $151 \%$ of the naturally generated total discharge in downstream areas. 
Numerous studies such as (Aeschbach-Hertig and Gleeson, 2012; Qureshi et al., 2010; Hoekstra et al., 2012) have studied groundwater depletion in the Indus Basin especially in the Punjab region. Satellite based quantification of groundwater abstraction and depletion is limited to GRACE studies. Despite poor spatial and temporal resolution, GRACE has a unique ability to assess total water available, i.e. surface as well as sub-surface water resources. Rodell et al. (2009) studied the groundwater depletion over the Indian states of Rajasthan, Haryana and Punjab by estimating the changes in terrestrial water storage using GRACE data for the period of August 2002 to October 2008 along with a land surface model. It was concluded that water withdrawals surpassed net recharge in the region and the groundwater depletion is at the mean rate of 4.0 $\pm 1.0 \mathrm{~cm}$ year $^{-1}$. Rodell et al. (2009) had also suggested that anthropogenic uses (human consumption) has a defining role in causing this severe groundwater depletion instead of natural variability. A similar study done over Northern India using GRACE data by Tiwari et al. (2009), resulted in same conclusion.

Chen et al. (2014) reassessed Northwest India for inter-annual variability in groundwater storage using the newer release of GRACE data (release-5) and an advance land surface model for 10-year period between January 2003 to December 2012, to find highly significant and profound groundwater depletion in the region.

Other than satellite based datasets, ground based measurements and hydrological models (cooperating both remote sensing and observed datasets) have been used to assess the groundwater depletion such as the studies done by Krishan et al. (2014) and Cheema et al. (2014). Krishan et al. (2014) conducted a field study to observe the groundwater levels using piezometers in multiple districts of Punjab. Monthly observed data for consecutive eight years between January 2006 to December 2013 was used to generate trends, and which indicated decreasing ground water levels 
over the time period. Whereas, Cheema et al. (2014) used a process based hydrologic model along with remotely sensed precipitation and evapotranspiration datasets to quantify groundwater abstraction and depletion over the irrigated areas of the Indus Basin. Punjab (Pakistan and India) and Haryana were found to be most vulnerable to groundwater depletion due to the prevalence of the groundwater driven irrigated agriculture especially the paddy-wheat cropping system. 


\section{CHAPTER 4: DATA AND METHODS}

The high altitude northern region of the Indus Basin remains covered with snow all year round. There are very limited gauges or stations installed for measuring magnitude of snow and other parameters due to inaccessibility and thus no in-situ long temporal record exists. Also several uncertainties arise due to the sparse density of gauges in mountain regions. Due to spatial nonuniformity and limited data availability, reliability of these datasets has always been a concern. Reliable observation of precipitation is very important for water management and application of drought or flood forecasts. While overcome these difficulties, remote sensing plays a crucial role in monitoring such high altitude and inaccessible regions of earth (Forsyethe et al., 2012) and provide spatially consistent and reliable datasets.

Multiple datasets have been used for the assessment of variability in hydro-climatic parameters such as precipitation, air temperature, and snow cover. In addition, satellite and ground measurement have also been used for groundwater resource assessment over Punjab.

For precipitation measurements, NOAA's PREC/L and NASA's MERRA-2 datasets has been used. NOAA's PREC/L (PRECipitation REConstruction over Land), is a monthly dataset with a global coverage from January 1948 to August 2018. It is available free in three spatial resolutions (https://www.esrl.noaa.gov/psd/data/gridded/data.precl.html). For the current study, fine resolution $0.5^{\circ}$ latitude $* 0.5^{\circ}$ longitude was used from January 1948 to December 2010 . The MERRA-2 (the second Modern-Era Retrospective analysis for Research and Applications; https://gmao.gsfc.nasa.gov/reanalysis/MERRA-2/) is a project that provides numerous datasets, especially atmospheric datasets beginning from 1980 with spatial resolution of $0.5^{\circ}$ latitude * $0.625^{\circ}$ longitude. For this study, monthly averaged 2-dimensional Land Surface Forcing data was 
used for measuring precipitation. It provides bias corrected three precipitation components: Liquid Water Convective Precipitation (PRECCUCORR), Liquid Water Large-Scale Precipitation (PRECLSCORR) and Snowfall (PRECSNOCORR). For air temperature measurements, MERRA2 monthly averaged 2-dimensional Single-Level Diagnostics data was used which provides air temperature data at different vertical heights. For this study, only datasets providing air temperature measurements at $2 \mathrm{~m}$ and $10 \mathrm{~m}$ was used. Also, both MERRA-2 datasets were used from January 1980 to December 2017.

The Moderate Resolution Imaging Spectroradiometer (MODIS) Snow Cover data products were used for identifying and quantifying the snow cover extent on land and for snow-covered ice on inland water. It is freely available from AQUA and TERRA satellite platforms. MODIS Snow Cover Monthly L3 Global $0.05^{\circ}$ CMG (https://modis.gsfc.nasa.gov/data/dataprod/mod10.php) data product from TERRA satellite platform was used for this study. It has temporal coverage from March 2000 to the present and a fine spatial resolution of $0.05^{\circ}$ latitude $* 0.05^{\circ}$ longitude. However, due to the presence of data gaps, the temporal coverage of January 2004 to December 2017 was used to maintain continuity of data.

The GRACE Tellus (Gravity Recovery \& Climate Experiment) data was used to determine the groundwater trend in Punjab. For this study, GRACE Tellus JPL (Monthly Mass Grids-Land) (https://grace.jpl.nasa.gov/data/get-data/) with $1^{\circ}$ latitude $* 1^{\circ}$ longitude spatial resolution from April 2002 to July 2016 was used.

Aquifer data for Punjab state was gathered from multiple reports prepared by the Central Ground Water Board (CGWB) of the Government of India (http://cgwb.gov.in). The CGWB had implemented a program named "Aquifer Mapping and Management Plan" on different districts of 
Punjab to analyze and assess the quality and quantity of ground water in aquifers. Table 1 provide a summary of all data.

Table 1. District-wise summary of aquifer characteristics of Punjab (Source: CGWB Reports)

\begin{tabular}{|c|c|c|c|c|c|c|c|c|c|c|}
\hline District & $\begin{array}{l}\text { Aquifer I } \\
\text { Thickness } \\
\text { below Pre- } \\
\text { Monsoon } \\
\text { Water } \\
\text { Level (m) }\end{array}$ & $\begin{array}{l}\text { Average } \\
\text { Specific } \\
\text { Yield }\end{array}$ & $\begin{array}{l}\text { Aquifer II } \\
\text { Thickness } \\
\text { below Pre- } \\
\text { Monsoon } \\
\text { Water } \\
\text { Level (m) }\end{array}$ & $\begin{array}{l}\text { Average } \\
\text { Value of } \\
\text { Storativity }\end{array}$ & $\begin{array}{l}\text { Average } \\
\text { Thickness of } \\
\text { Piezometric } \\
\text { Level (m bgl) }\end{array}$ & $\begin{array}{l}\text { Aquifer III } \\
\text { Thickness of the } \\
\text { Granular Zone in } \\
\text { Confined Aquifer } \\
\text { Down to Explored } \\
\text { Depth (m) }\end{array}$ & $\begin{array}{l}\text { Aquifer III } \\
\text { Thickness of } \\
\text { Piezometric } \\
\text { Level (m bgl) }\end{array}$ & $\begin{array}{l}\text { Average } \\
\text { Value of } \\
\text { Storativity }\end{array}$ & $\begin{array}{l}\text { Fresh Water Area } \\
\left(\mathrm{m}^{2}\right)\end{array}$ & $\begin{array}{l}\text { Dynamic } \\
\text { Groundwater } \\
\text { Resources }\left(\mathrm{m}^{3}\right)\end{array}$ \\
\hline Ludhiana & 40.472 & 0.072 & 35.333 & 0.002 & 100.333 & 35.500 & 0.000 & 0.002 & 3586900000.000 & 2126740000.000 \\
\hline Amritsar & 79.375 & 0.072 & 54.125 & 0.002 & & 36.250 & & & 2583400000.000 & 1753540000.000 \\
\hline Barnala & 53.667 & 0.072 & 58.067 & 0.003 & 30.400 & 21.000 & 30.400 & 0.003 & 1351700000.000 & 615180000.000 \\
\hline Bhatinda & 69.857 & 0.072 & Saline Wate & er Aquifer & & & & & 1135200000.000 & 1442000000.000 \\
\hline Faridkot & 58.500 & 0.072 & Saline Wate & er Aquifer & & & & & 983600000.000 & 615000000.000 \\
\hline Fatehgarh Sahib & 58.200 & 0.072 & 32.200 & 0.001 & 164.800 & 25.750 & 195.670 & 0.001 & 1116700000.000 & 587000000.000 \\
\hline $\begin{array}{l}\text { Ferozpur \& } \\
\text { Fazilka }\end{array}$ & 106.400 & 0.072 & Saline Wate & er Aquifer & & & & & 4808900000.000 & 4608440000.000 \\
\hline Pathankot & 38.750 & 0.072 & 84.000 & 0.000 & & & & & 728430000.000 & 1644730000.000 \\
\hline Gurdaspur & 55.200 & 0.072 & 64.444 & 0.002 & & 63.714 & & 0.002 & 2544500000.000 & 319590000.000 \\
\hline Mansa & 70.200 & 0.072 & Saline Wate & er Aquifer & & & & & & \\
\hline Moga & 122.200 & 0.072 & Saline Wate & er Aquifer & & & & & 2172200000.000 & 1165700000.000 \\
\hline Muktsar & 12.625 & 0.072 & Saline Wate & er Aquifer & & & & & 2284060000.000 & 761250000.000 \\
\hline Patiala & 36.500 & 0.072 & 28.250 & 0.002 & 95.463 & 67.500 & 189.725 & 0.002 & 3302700000.000 & 1531080000.000 \\
\hline Ropar & 34.808 & 0.072 & 23.098 & 0.000 & 132.182 & 15.660 & $0(34.40)$ & 0.000 & 1370400000.000 & 419470000.000 \\
\hline SAS Nagar & 34.667 & 0.072 & 25.333 & 0.002 & 111.133 & 78.000 & $0(34.40)$ & 0.001 & 1189000000.000 & 289630000.000 \\
\hline Sangrur & 36.889 & 0.072 & 28.889 & 0.002 & 165.522 & 25.222 & 190.978 & 0.002 & 3318300000.000 & 1735170000.000 \\
\hline Punjab & 56.769 & 0.072 & 43.374 & 0.002 & 114.262 & 40.955 & 151.693 & 0.002 & & \\
\hline
\end{tabular}

The detailed characteristics of aquifers, up to $300 \mathrm{~m}$ below ground, are available on a district level for Punjab. All district values were averaged to represent the overall aquifer characteristics of Punjab, and only fresh water aquifers were considered. Using Table 1, dynamic and in-storage groundwater resources of aquifers I, II and III, were computed as per according to CGWB report. The following formulas were used to do so: -

\begin{tabular}{|c|c|c|c|c|c|c|}
\hline $\begin{array}{l}\text { Unconfined Aquifer I } \\
\text { In-storage } \\
\text { Groundwater } \\
\text { Resources }\end{array}$ & $=$ & $\begin{array}{l}\text { Thickness of the aquifer } \\
\text { (granular / productive } \\
\text { zone) below the zone of } \\
\text { water level fluctuation } \\
\text { down to the bottom layer }\end{array}$ & $*$ & $\begin{array}{l}\text { Specific } \\
\text { yield of } \\
\text { the aquifer }\end{array}$ & $*$ & $\begin{array}{l}\text { Spatial } \\
\text { extent of } \\
\text { the } \\
\text { aquifer }\end{array}$ \\
\hline
\end{tabular}




\begin{tabular}{|c|c|c|c|c|c|c|}
\hline $\begin{array}{c}\text { Confined Aquifer In- } \\
\text { storage Groundwater } \\
\text { Resources } \\
\text { (within the piezometer) }\end{array}$ & $=$ & $\begin{array}{l}\text { Thickness of the water } \\
\text { column in Piezometer of } \\
\text { particular confined } \\
\text { aquifer up to the top } \\
\text { layer of same confined } \\
\text { aquifer }\end{array}$ & $*$ & $\begin{array}{l}\text { Storativity } \\
\text { of the } \\
\text { confined } \\
\text { aquifer }\end{array}$ & $*$ & $\begin{array}{l}\text { Spatial } \\
\text { extent of } \\
\text { the } \\
\text { confined } \\
\text { aquifer }\end{array}$ \\
\hline
\end{tabular}

(Specific Yield Concept)

confined Aquifer I In-
storage Groundwater
Resources
(within aquifer
thickness)

\author{
Thickness of the \\ confined aquifer \\ = (granular / productive \\ zone) down to the \\ bottom layer of confined \\ aquifer or exploitable \\ depth of $300 \mathrm{~m}$
}
Specific Spatial
* yield of $*$ extent of
the
confined
aquifer

For Aquifer II \& III, total in-storage groundwater resources is equal to summation of instorage groundwater resources (storativity concept) and in-storage groundwater resources (specific yield concept).

In addition, data on surface water potential, area under paddy cultivation, net replenishable groundwater potential, net groundwater availability and water requirement of paddy was gathered from literature (Kaur et al., 2008; Statistical Abstract of Punjab, various issues).

To understand the nature and dynamics of hydro-climatic variables, a Kendall-tau test was conducted on precipitation, air-temperature and snow cover datasets. Spatial maps on trend values of precipitation and air temperature were generated using ArcMap to shows the regions which are under the influence of particular parameters. The color code and dots on spatial maps, respectively, represents $r$-values and grid points at which significant trend is found $(p<0.05)$. 


\section{CHAPTER 5: RESULTS AND DISCUSSION}

\subsection{MERRA-2 Precipitation}

\subsubsection{Convective Precipitation}

To determine the temporal and spatial changes in precipitation, trend analysis was conducted on spatially averaged and actual spatial values of convective precipitation on monthly, seasonal and annual time scales.

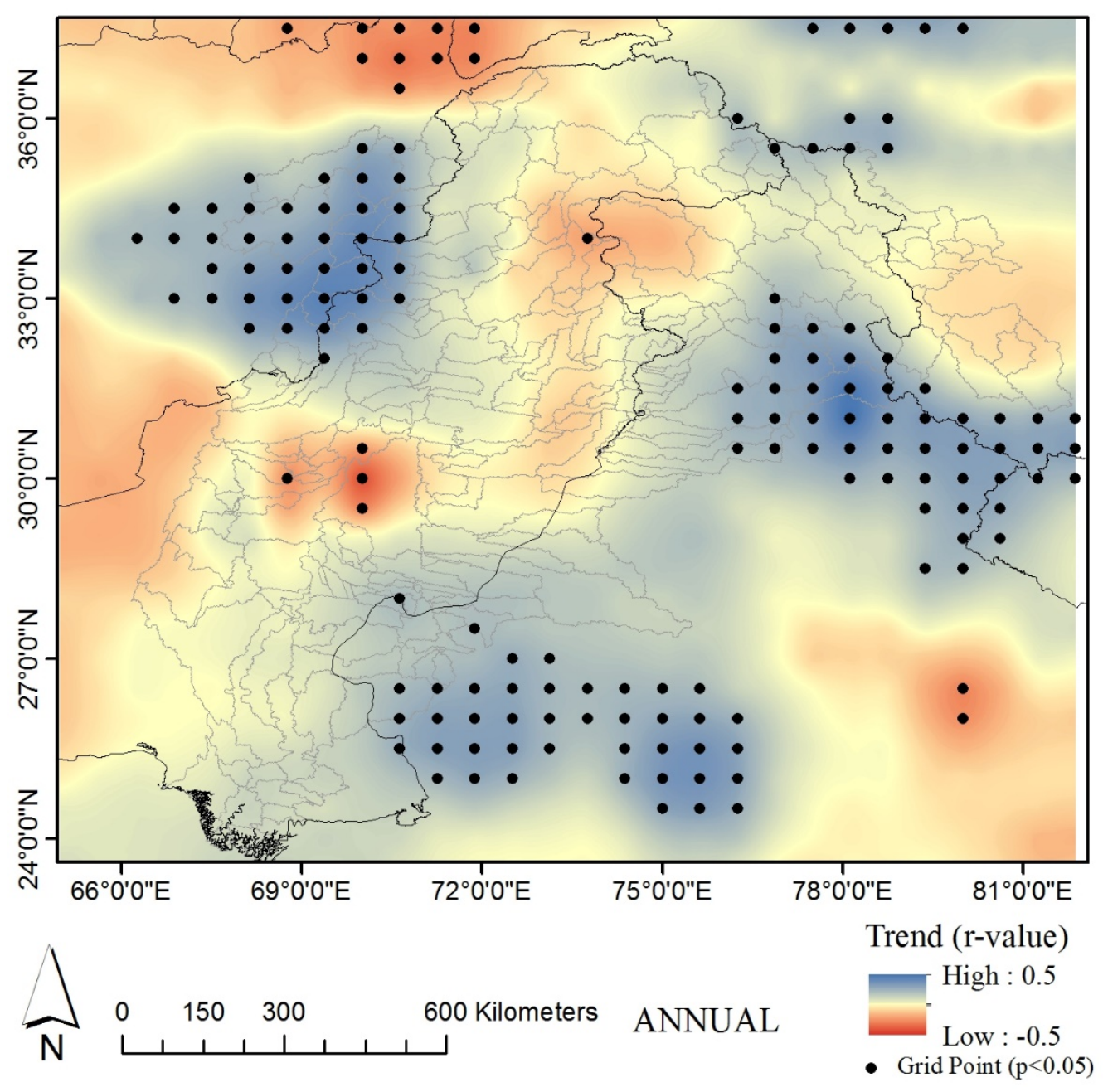

Figure 2. Spatial trend map of annual convective precipitation 
Table 2. Monthly, seasonal and annual trends of spatially averaged MERRA-2 convective precipitation.

Asterisk $\left(^{*}\right)$ symbol shows time interval with significant $p$-value $(p<0.05)$

\begin{tabular}{|l|l|l|}
\hline Time Interval & $\mathrm{r}$ & $\mathrm{p}$ \\
\hline January & -0.11 & 0.35 \\
\hline February & -0.13 & 0.27 \\
\hline March & -0.16 & 0.17 \\
\hline April & 0.08 & 0.50 \\
\hline May* & 0.23 & 0.04 \\
\hline June* & 0.25 & 0.02 \\
\hline July & 0.11 & 0.35 \\
\hline August & -0.03 & 0.82 \\
\hline September & 0.16 & 0.16 \\
\hline October & 0.01 & 0.92 \\
\hline November & 0.05 & 0.67 \\
\hline December & -0.21 & 0.07 \\
\hline DJF & -0.21 & 0.07 \\
\hline MAM & 0.12 & 0.29 \\
\hline JJA & 0.07 & 0.53 \\
\hline SON & 0.15 & 0.18 \\
\hline Annual & & \\
\hline & & \\
\hline & & \\
\hline & & \\
\hline & & \\
\hline & & \\
\hline
\end{tabular}


The spatially averaged annual convective precipitation showed no significant trend $(p<0.05)$ (Table 2), implying the overall annual convective precipitation over the region has remain unchanged. The spatial trend map on annual convective precipitation justifies the interpretation of an unchanged convective precipitation system except on the eastern and western edges of the Indus Basin (IB), where it showed a significant increasing trend (Figure 2).

Similarly, the spatially averaged seasonal convective precipitations (DJF, MAM, JJA \& SON) showed no significant trend (Table 2). However, spatial trend maps of seasonal convective precipitation showed some regions that had significant increasing or decreasing trends (Figure 3). In particular, the DJF and MAM seasons showed an increasing and decreasing trend, respectively, across most of the Indus Basin.

The trends of spatially averaged monthly convective precipitations remained unchanged (statistically insignificant trend) except for May and June, which had showed a significant increasing trend (Table 2). Figure 4A \& 4B shows maps of monthly convective precipitation trends. It is clearly visible from the map of May and June months that most of the significant points lies on the edge and outside the boundaries of the Indus Basin. Therefore, spatially averaging convective precipitation for these months identifies the significance for the overall Indus Basin.

In order to summarize the convective precipitation analysis over the Indus Basin, we concluded that no statistically significant trend was found on annual, seasonal and monthly scales except for May and June. Despite the increasing monthly trend, there were no significant seasonal trends. 


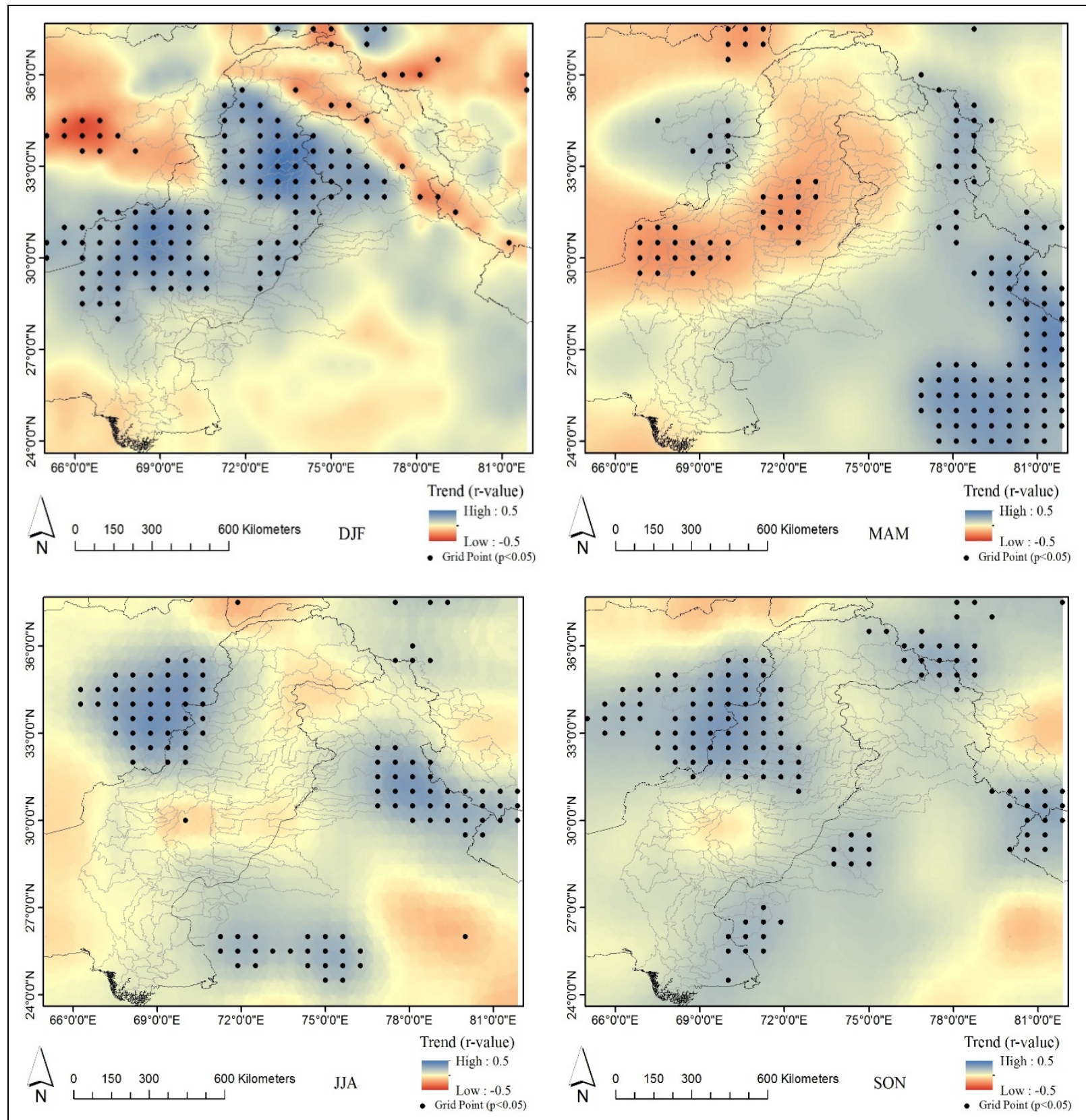

Figure 3. Spatial trend map of seasonal convective precipitation 

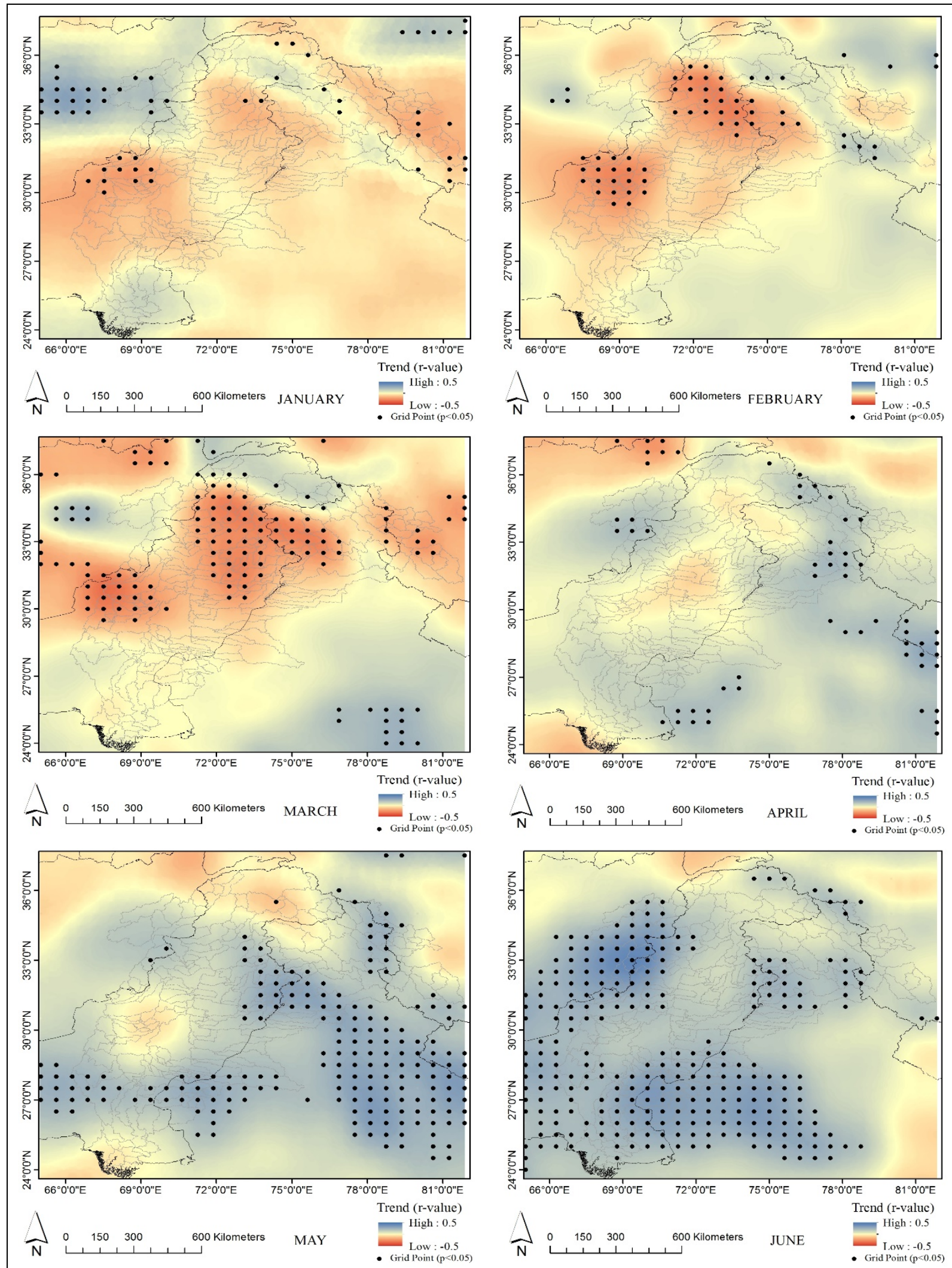

Figure 4A. Spatial trend map of monthly convective precipitation (JAN-FEB-MAR-APR-MAY-JUNE) 


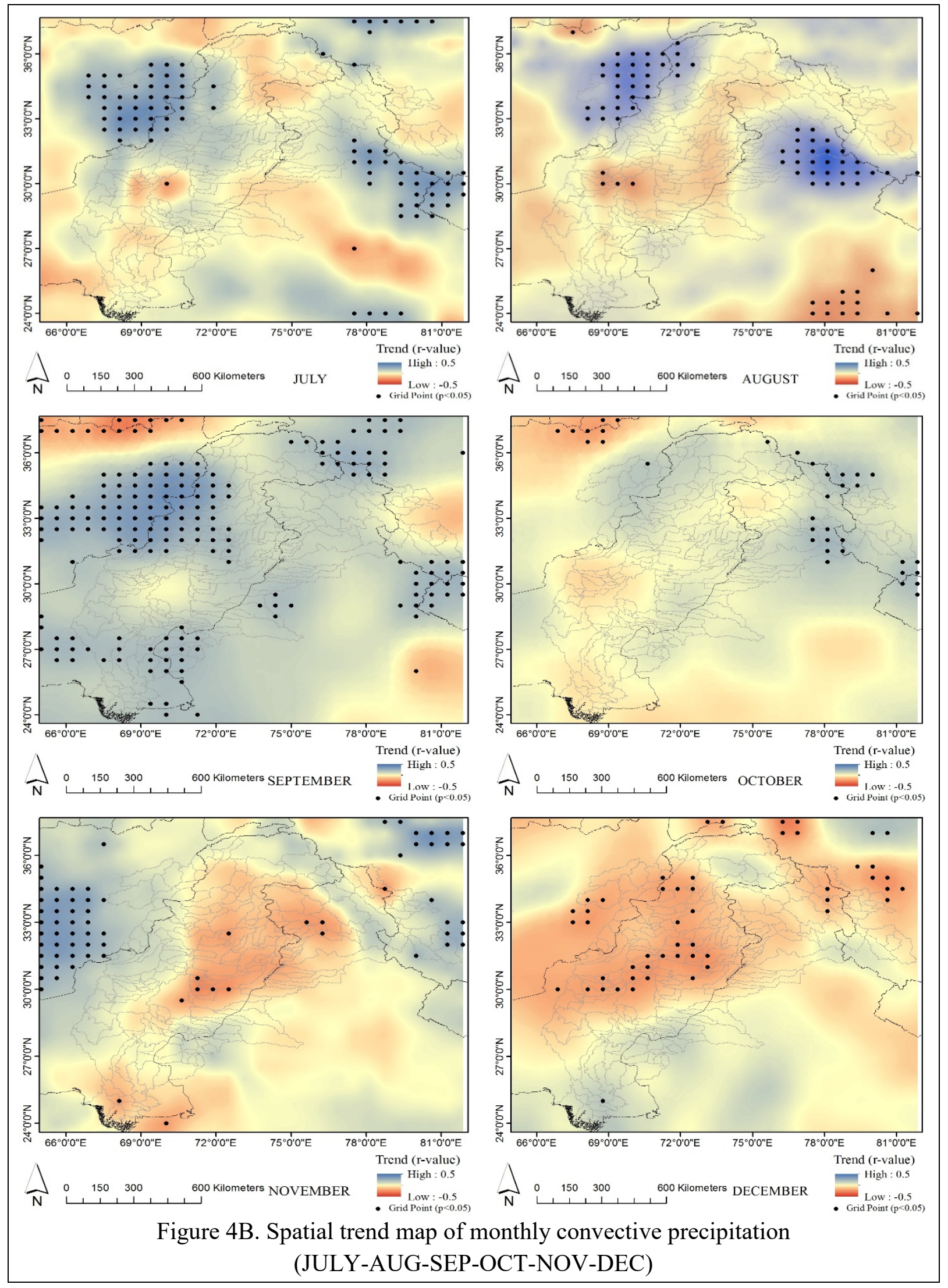




\subsubsection{Large Scale Precipitation}

The spatially averaged annual large scale precipitation showed a significant increasing trend (Table 3). The map of annual large scale precipitation (Figure 5) clearly distinguishes the dominant regions where the change (increasing trend) is more prominent. It suggests that the contribution of large scale precipitation has increased in total annual precipitation over the Indus Basin.

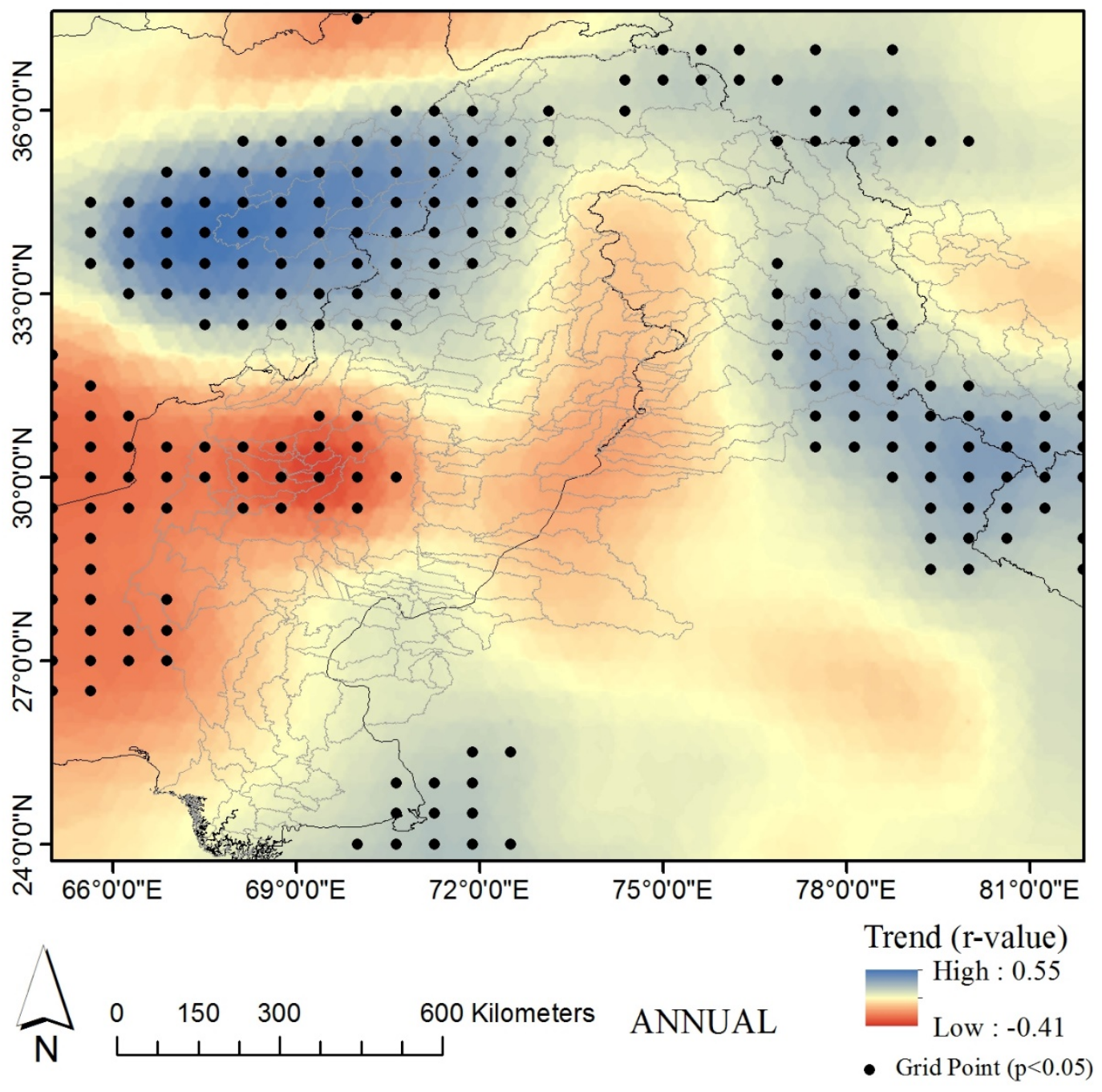

Figure 5. Spatial trend map of annual large scale precipitation 
Table 3. Monthly, seasonal and annual trends of spatially averaged MERRA-2 large scale precipitation

Asterisk $\left(^{*}\right)$ symbol shows time interval with significant $p$-value $(p<0.05)$

\begin{tabular}{|l|l|l|}
\hline Time Interval & $\mathrm{r}$ & $\mathrm{p}$ \\
\hline January & 0.01 & 0.92 \\
\hline February & 0.07 & 0.55 \\
\hline March & -0.12 & 0.28 \\
\hline April & 0.14 & 0.23 \\
\hline May & 0.12 & 0.32 \\
\hline June* & 0.23 & 0.04 \\
\hline July* & 0.25 & 0.02 \\
\hline August & 0.12 & 0.28 \\
\hline September & 0.10 & 0.38 \\
\hline October & -0.04 & 0.71 \\
\hline November & 0.15 & 0.19 \\
\hline December & -0.17 & 0.12 \\
\hline DJF & 0.03 & 0.82 \\
\hline MAM & 0.03 & 0.025 \\
\hline JJA* & 0.30 & \\
\hline SON & & \\
\hline & & \\
\hline Annual* & & \\
\hline & & \\
\hline
\end{tabular}


Seasonal trend analysis gives an interesting insight into the contribution of seasonal large scale precipitation to the annual large scale precipitation. The spatially averaged seasonal large scale precipitations for DJF, MAM \& SON season showed no significant trend (Table 3).

However, spatially averaged seasonal large scale precipitations for JJA showed a very significant increasing trend, which is supported by an increasing trend for June and July spatially averaged large scale precipitation. The maps highlight the hotspot regions where seasonal changes have been occurring (Figure 6). It is inferred from the JJA seasonal map that the control of JJA contribution to total large scale precipitation for the Indus Basin, originates from the northern Indus Basin. Thus, the prevalence of a decreasing trend in the southern Indus Basin has not affected the total spatial average of the entire region. Similar results were derived from the annual map (Figure $5)$.

As mentioned earlier, except June and July, the trends of spatially averaged monthly large scale precipitation were not significant (Table 3). Figure 7A \& 7B shows maps of monthly large scale precipitation trends.

The whole large scale precipitation over the Indus Basin shows a statistically significant trend on annual scale which results from an evidently significant increased JJA trend, which has further supported by increasing June and July months trends.

The notable conclusion of the spatial trend analysis is that the central parts of the Indus Basin are statistical unchanged and most of the trends are found along the boundaries and surrounding regions of the Indus Basin. 


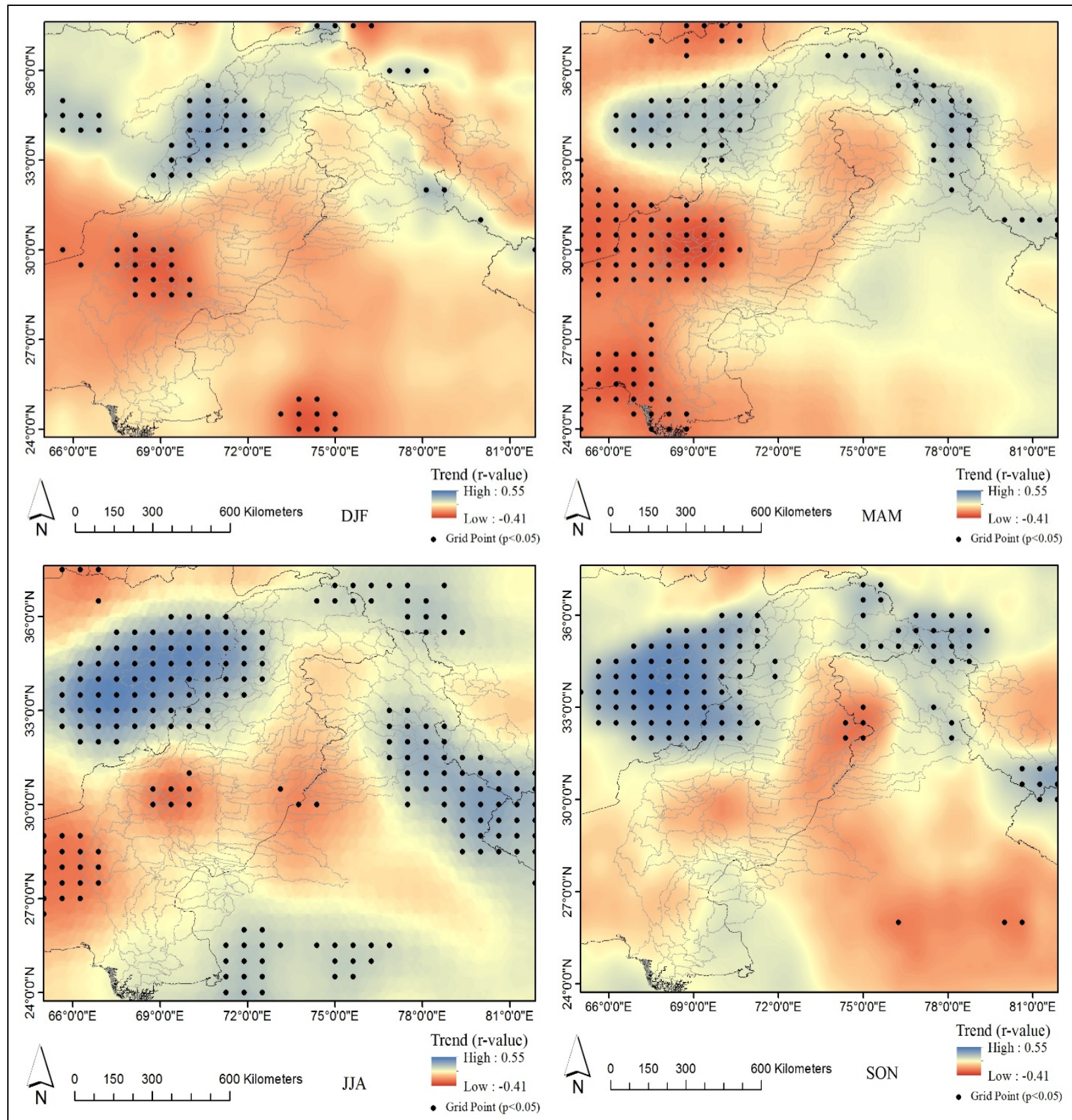

Figure 6. Spatial trend map of seasonal large scale precipitation 


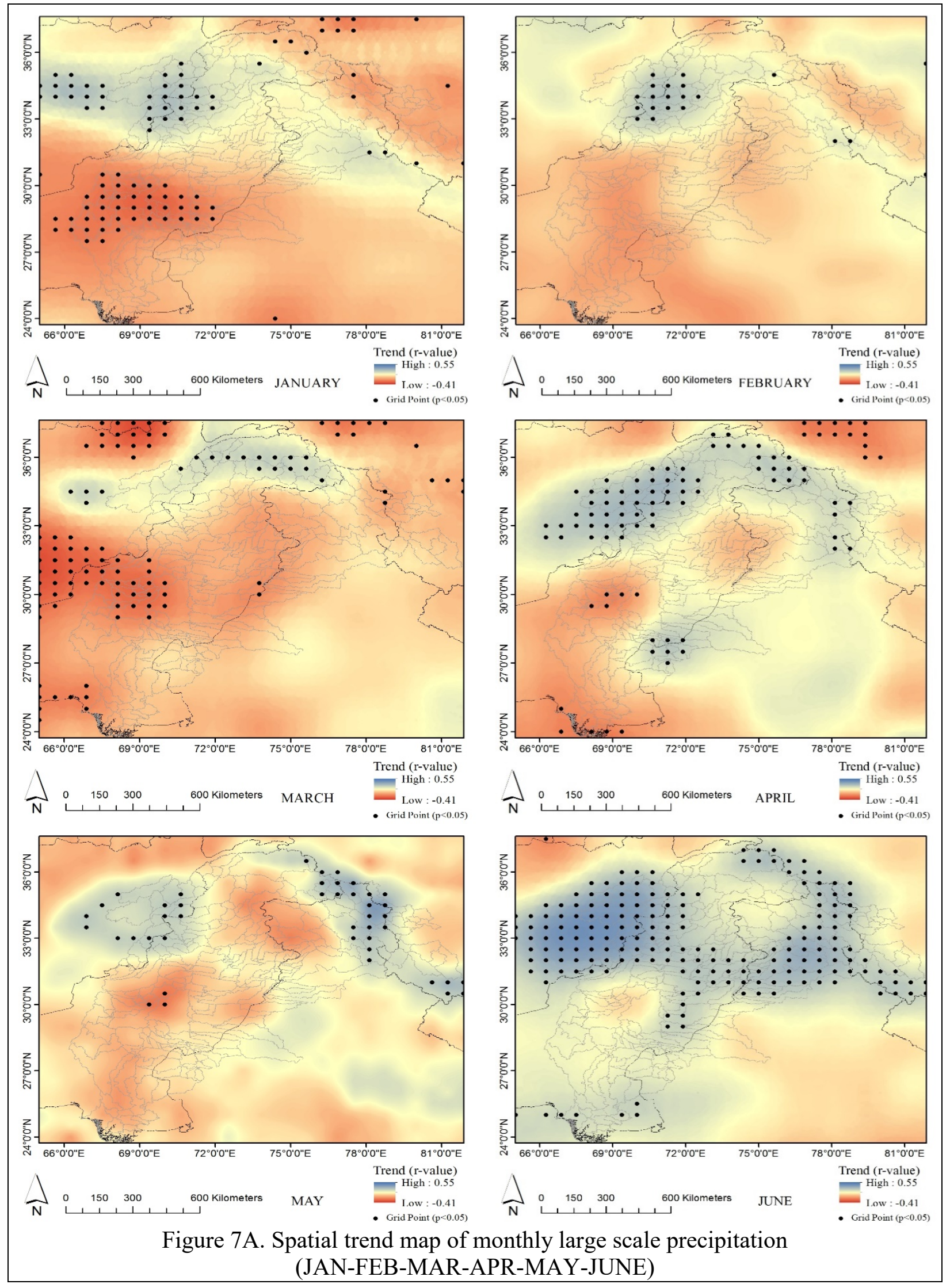



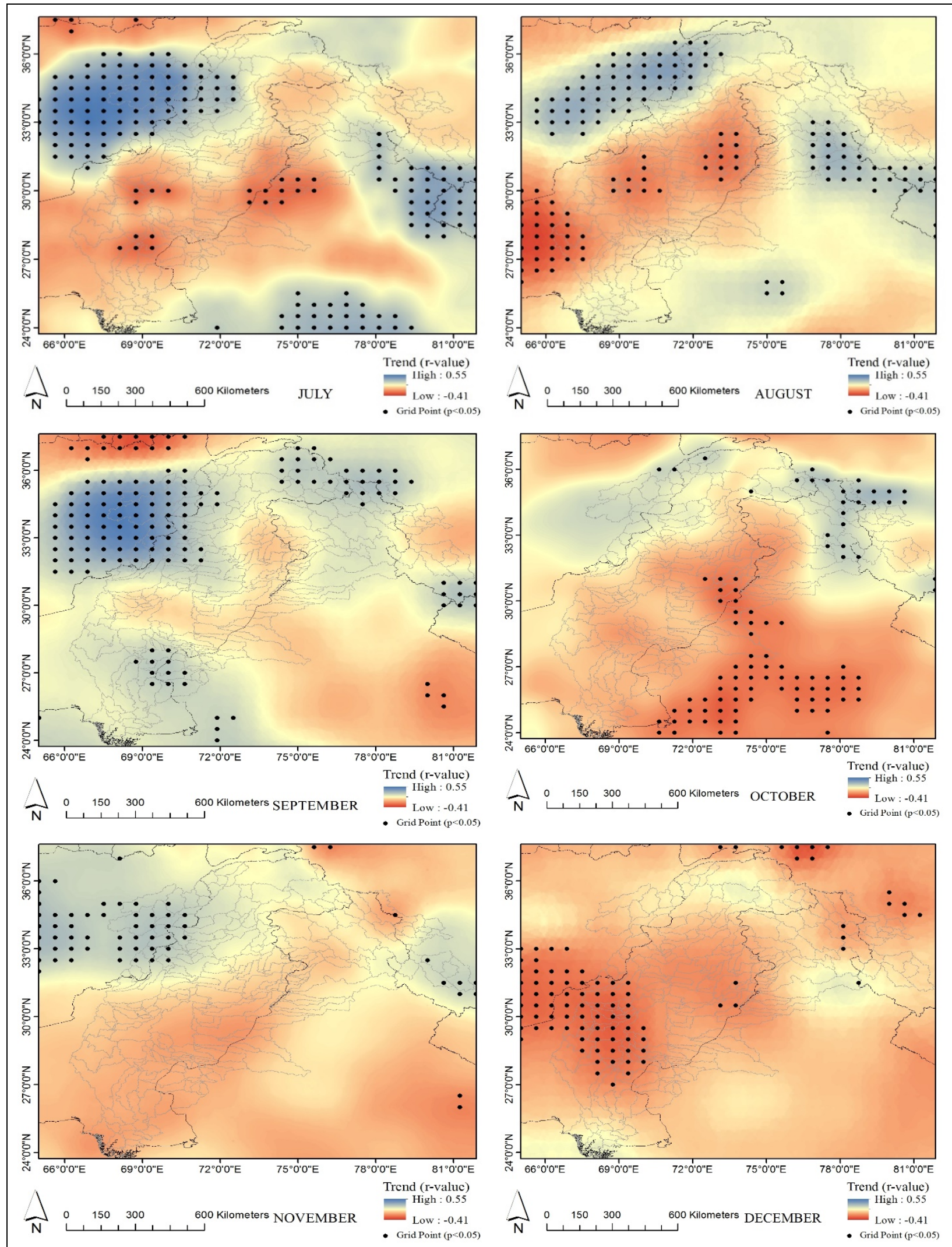

Figure 7B. Spatial trend map of monthly large scale precipitation (JULY-AUG-SEP-OCT-NOV-DEC) 


\subsubsection{Snowfall}

No significant trends were found on annual, seasonal and monthly scales (Table 4). The maps

(Figure 8, 19, 20A \& 20B) shows annual, seasonal and monthly snowfall trends respectively. It is depicted from the maps that most of regional significance has occurred on the northern regions but mostly out of the boundary limits of the Indus Basin.

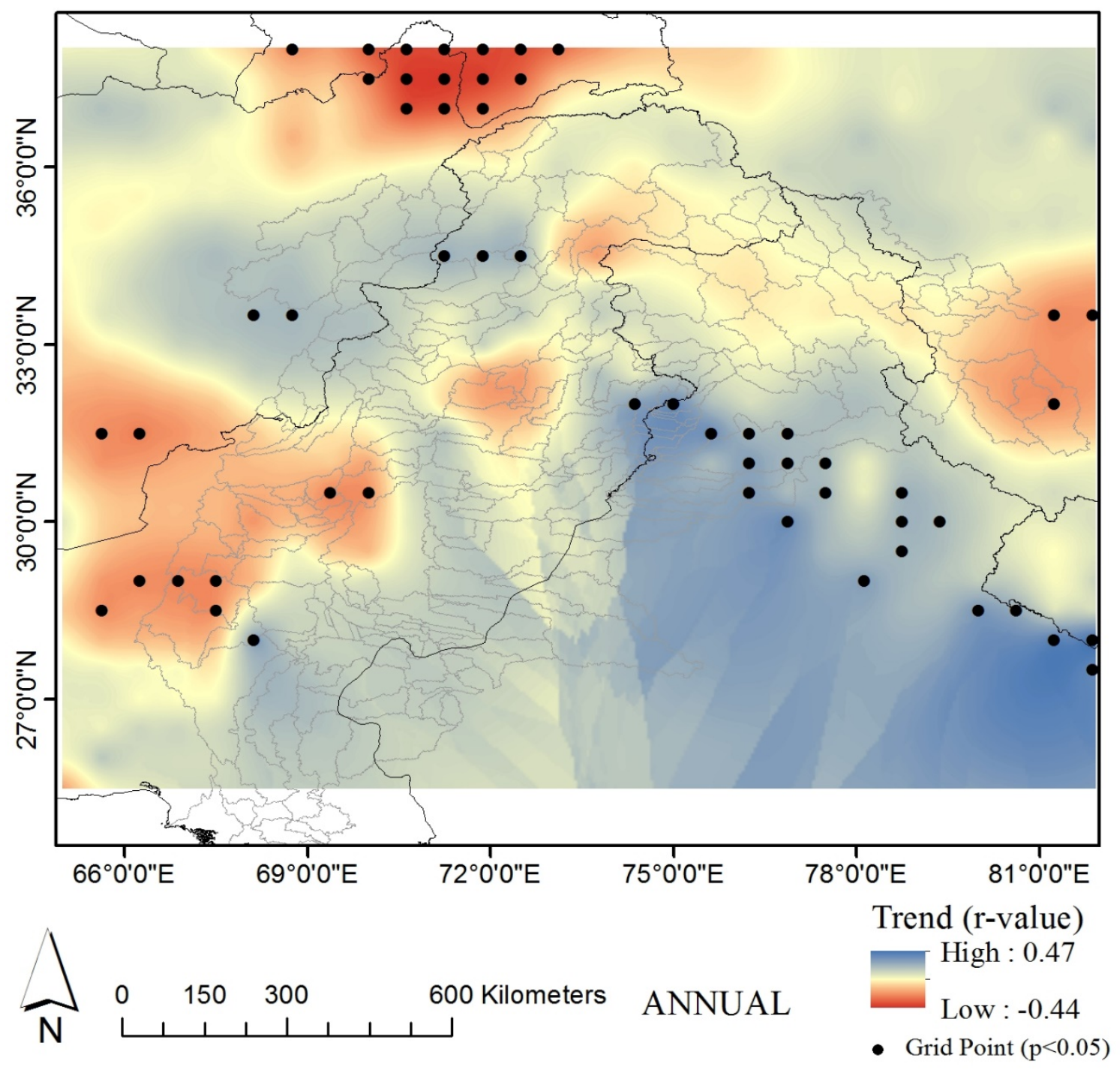

Figure 8 Spatial trend map of annual snowfall 
Table 4. Monthly, seasonal and annual trends of spatially averaged MERRA-2 snowfall

\begin{tabular}{|l|l|l|}
\hline Time Interval & $\mathrm{r}$ & $\mathrm{p}$ \\
\hline January & 0.06 & 0.62 \\
\hline February & 0.19 & 0.08 \\
\hline March & -0.11 & 0.34 \\
\hline April & 0.01 & 0.90 \\
\hline May & -0.02 & 0.84 \\
\hline June & -0.001 & 1.00 \\
\hline July & -0.07 & 0.53 \\
\hline August & 0.09 & 0.42 \\
\hline September & 0.06 & 0.59 \\
\hline October & -0.09 & 0.43 \\
\hline November & 0.10 & 0.38 \\
\hline December & -0.11 & 0.34 \\
\hline DJF & 0.21 & 0.07 \\
\hline MAM & -0.11 & 0.38 \\
\hline JJA & -0.02 & 0.88 \\
\hline SON & 0.02 & 0.84 \\
\hline Annual & 0.10 & 0.38 \\
\hline & & \\
\hline
\end{tabular}




\subsubsection{Total Precipitation}

The spatially averaged annual total precipitation showed no significant trend (Table 5), implying the overall annual total precipitation over the region has remain unchanged, despite the presence of significantly increasing annual large scale precipitation trend. In support of this, the trend map of annual total precipitation also shows no changes except on the boundary and surrounding regions (Figure 9).

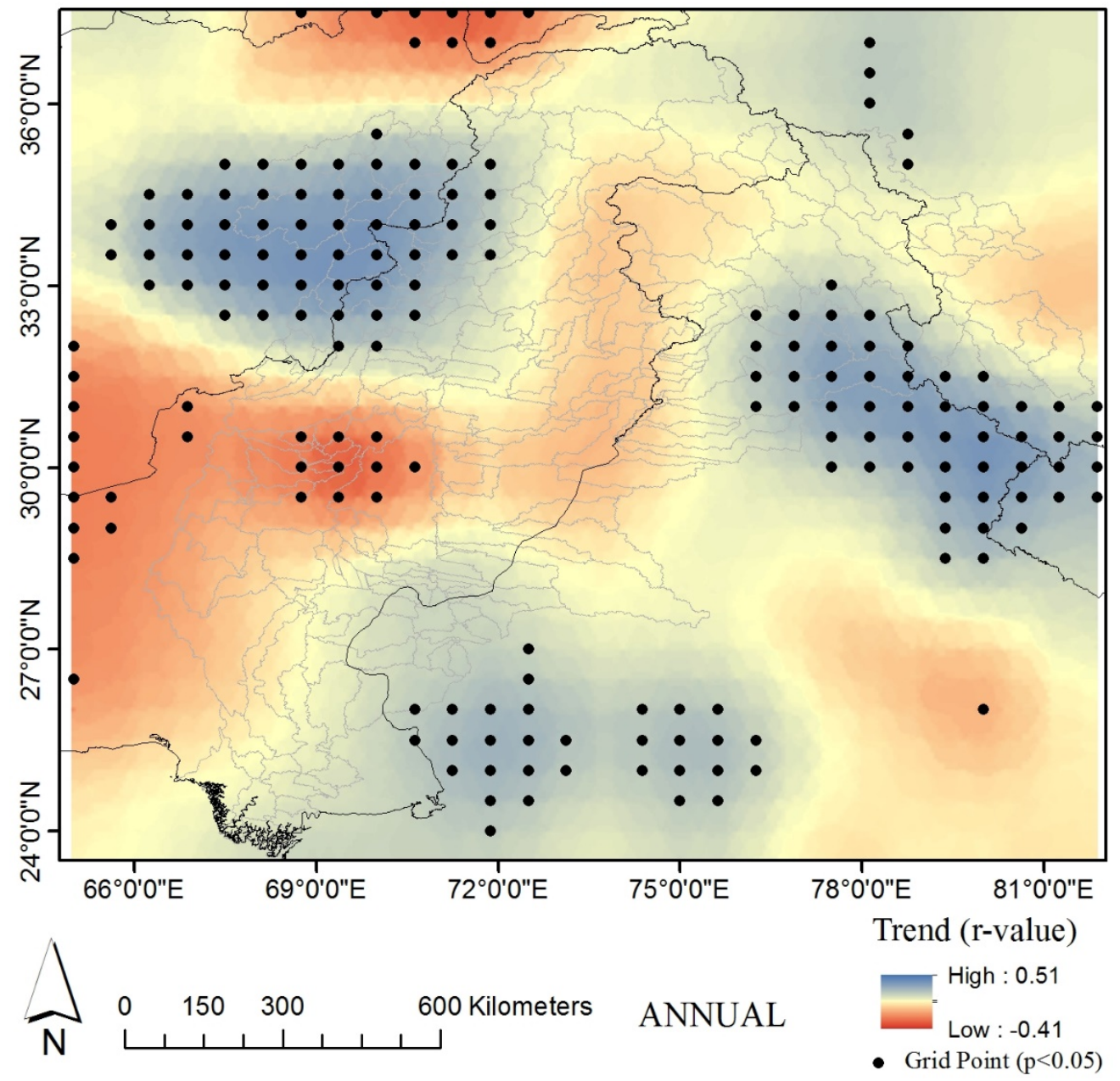

Figure 9. Spatial trend map of annual total precipitation 
Table 5. Monthly, seasonal and annual trends of spatially averaged MERRA-2 total precipitation Asterisk (*) symbol shows time interval with significant $p$-value $(\mathrm{p}<0.05)$

\begin{tabular}{|l|l|l|}
\hline Time Interval & $\mathrm{r}$ & $\mathrm{p}$ \\
\hline January & -0.001 & 1.00 \\
\hline February & 0.08 & 0.50 \\
\hline March & -0.15 & 0.18 \\
\hline April & 0.14 & 0.23 \\
\hline May & 0.13 & 0.24 \\
\hline June* & 0.26 & 0.02 \\
\hline July & 0.21 & 0.07 \\
\hline August & 0.07 & 0.52 \\
\hline September & 0.14 & 0.23 \\
\hline October & -0.007 & 0.96 \\
\hline November & 0.13 & 0.27 \\
\hline December & -0.18 & 0.11 \\
\hline DJF & 0.08 & 0.49 \\
\hline MAM & 0.04 & 0.74 \\
\hline JJA & 0.18 & 0.11 \\
\hline SON & 0.09 & 0.41 \\
\hline Annual & 0.19 & 0.09 \\
\hline
\end{tabular}


Although the spatially averaged seasonal total precipitations (DJF, MAM, JJA \& SON) showed no significant trend (Table 5), trend maps of seasonal total precipitation exhibit hotspot regions where significant increasing and decreasing trend are evident (Figure 10).

The trends of spatially averaged monthly total precipitation are not significant except for June, which showed a significant increasing trend (Table 5). Even though the June month trend shows a promisingly increasing trend, it was insufficient to produce a JJA seasonal trend. Figure 11A \&11B shows maps of monthly total precipitation trends.
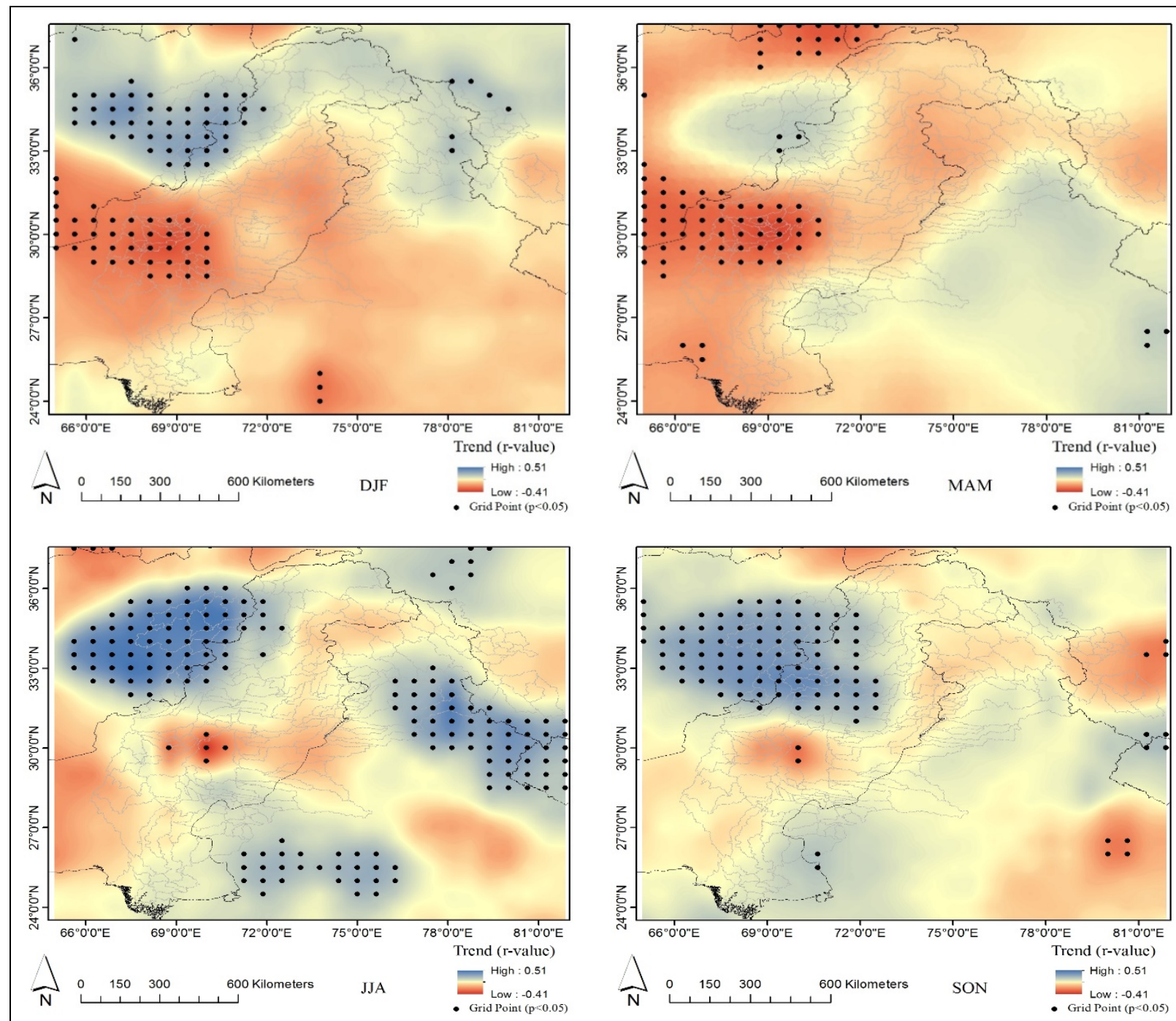

Figure 10. Spatial trend map of seasonal total precipitation 

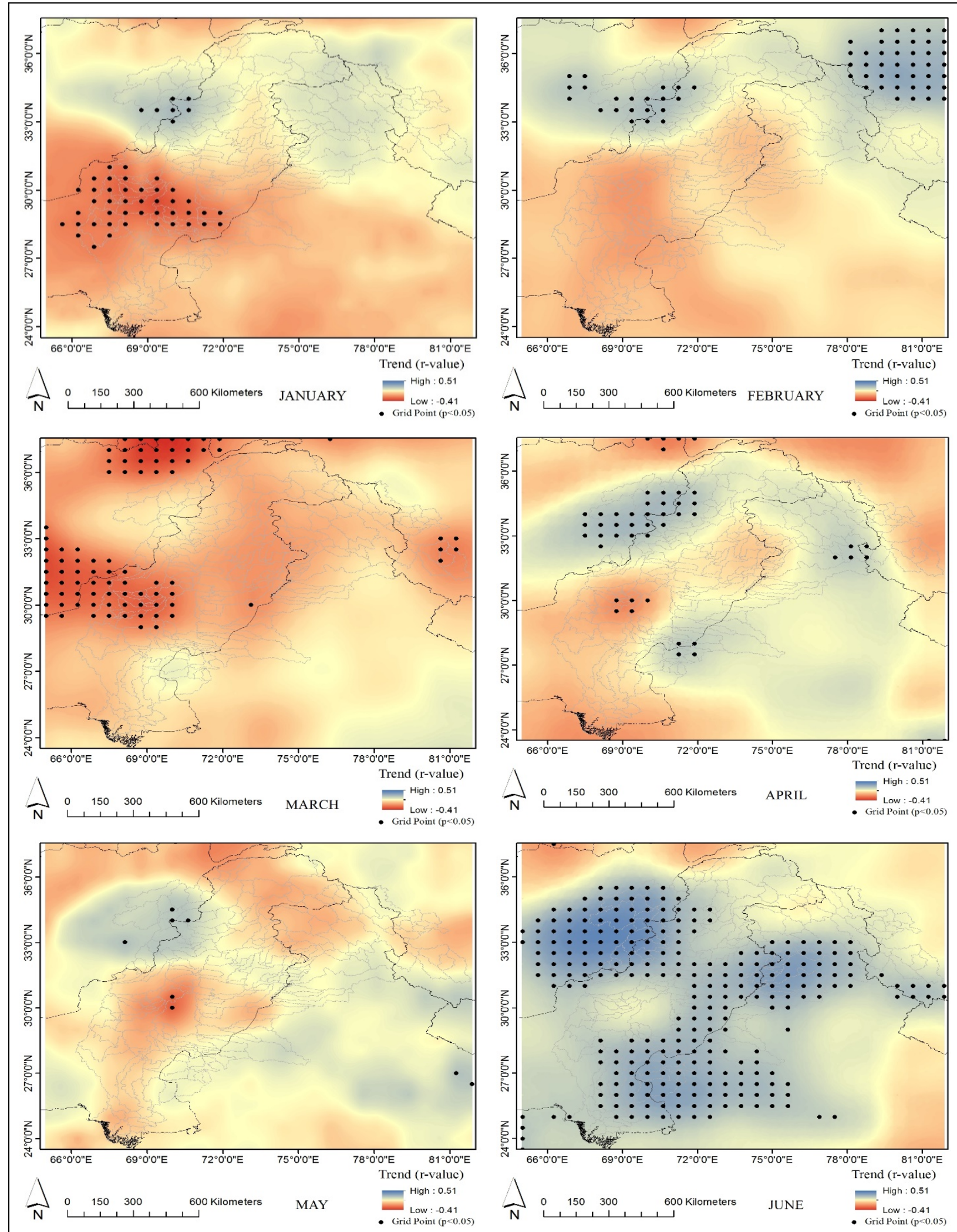

Figure 11A. Spatial trend map of monthly total precipitation

(JAN-FEB-MAR-APR-MAY-JUNE) 


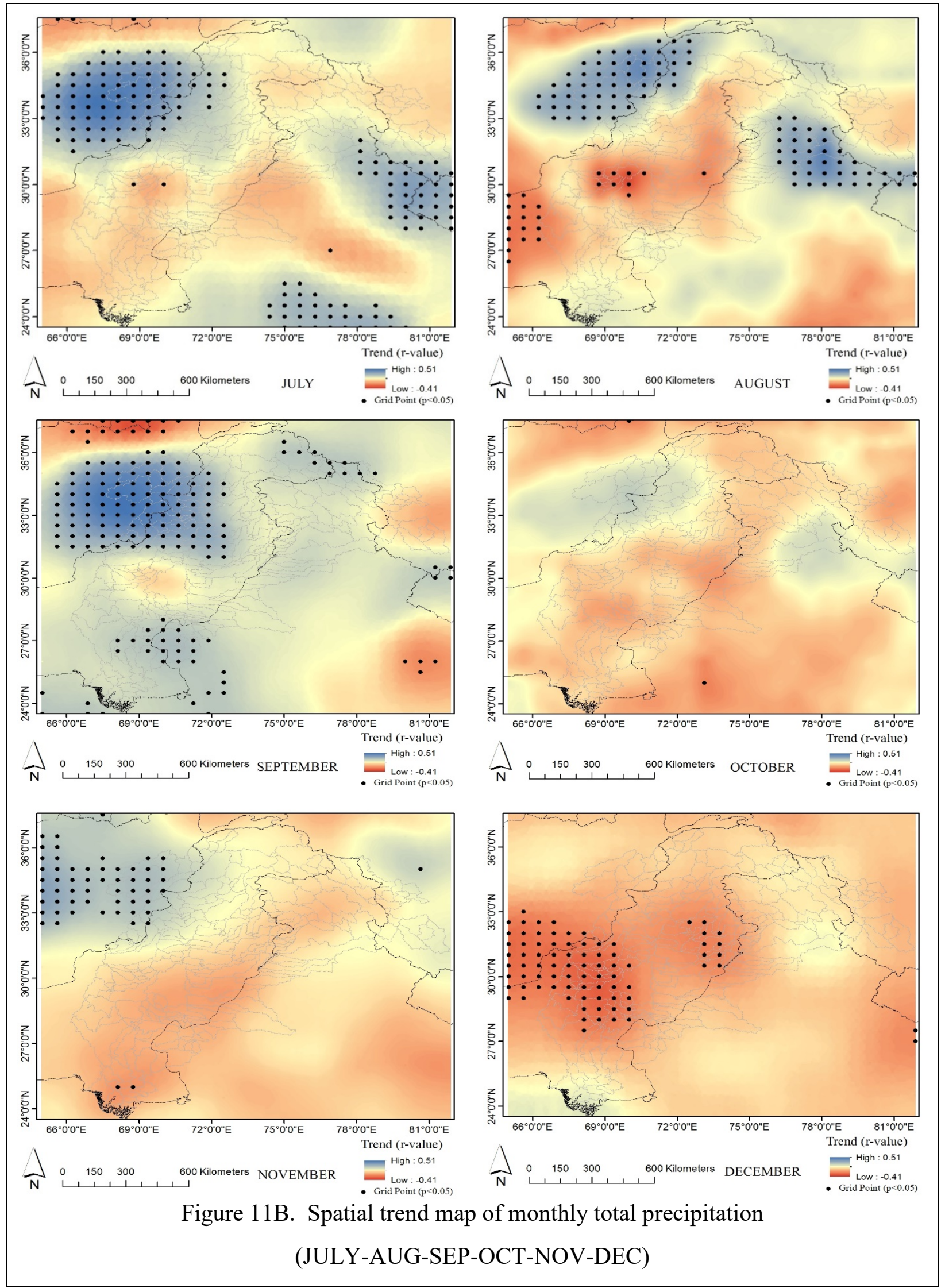


To summarize the MERRA 2 precipitation results (for all type of precipitations, i.e. convective precipitation, large-scale precipitation, snowfall and total precipitation), the Indus Basin shows no significant trends in precipitation. Only on the edges of the region, in Afghanistan and China (eastern and western boundary regions of the Indus Basin), shows evidence of changing precipitation, otherwise the central Indus Basin (majority of the Pakistan portion of the basin) has no significant trend.

\subsection{PREC/L Precipitation}

The trend test on spatially averaged annual, seasonal and monthly precipitation was not significant except for the month of June (Table 6).

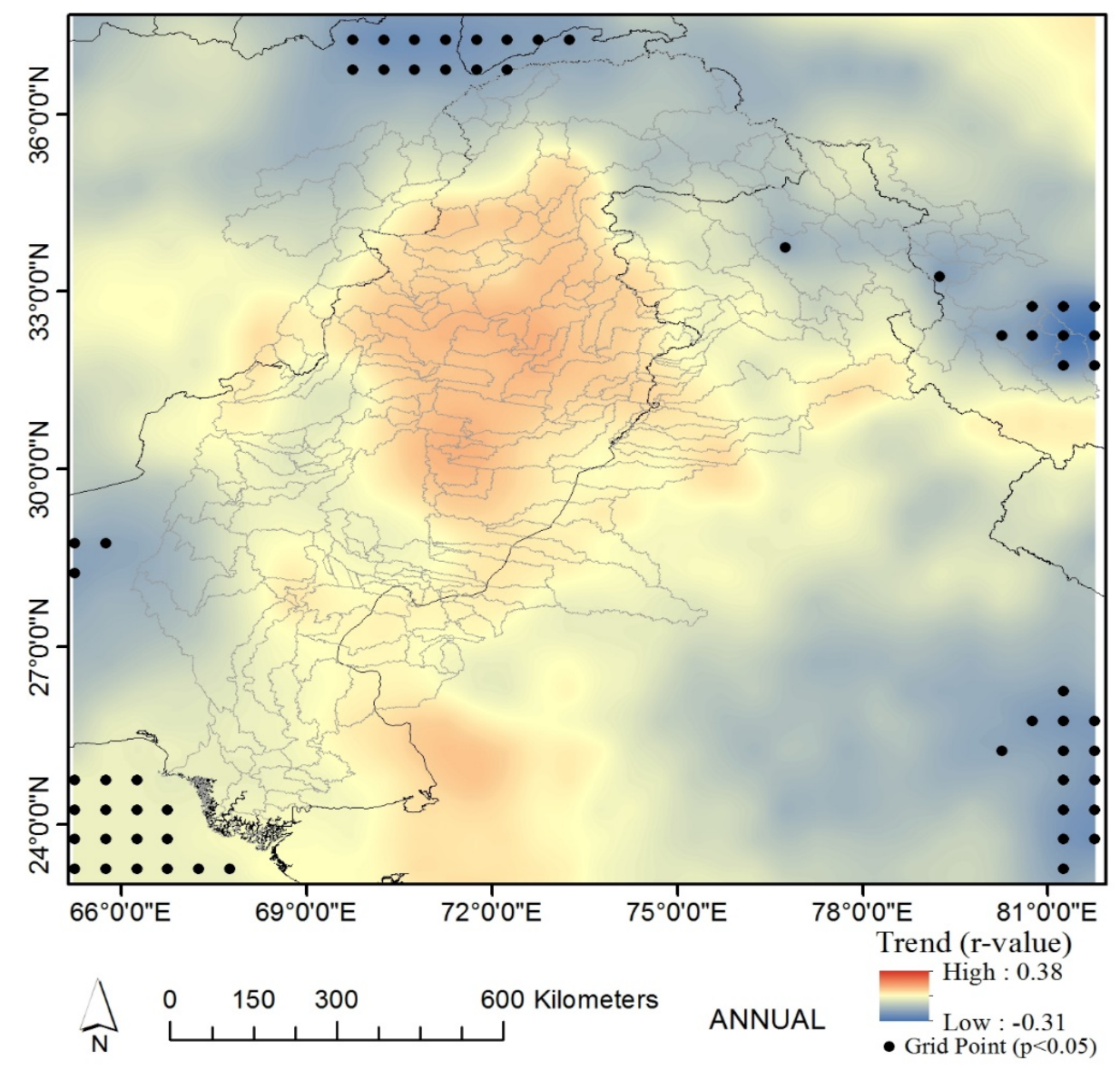

Figure 12. Spatial trend map of PREC/L annual precipitation 
Trend maps (Figure 12, Figure 13 \& Figure 21A \& 21B) provide an insight regarding patterns of respectively annual, seasonal and monthly precipitation trends in the Indus Basin.

Table 6. Monthly, seasonal and annual trends of spatially averaged PREC/L precipitation Asterisk $(*)$ symbol shows time interval with significant $p$-value $(p<0.05)$

\begin{tabular}{|l|l|l|}
\hline Time Interval & $\mathrm{r}$ & $\mathrm{p}$ \\
\hline January & -0.14 & 0.11 \\
\hline February & 0.08 & 0.36 \\
\hline March & -0.13 & 0.13 \\
\hline April & -0.09 & 0.32 \\
\hline May & 0.07 & 0.38 \\
\hline June* & 0.24 & 0.004 \\
\hline July & -0.08 & 0.33 \\
\hline August & -0.03 & 0.70 \\
\hline September & -0.01 & 0.90 \\
\hline October & -0.04 & 0.66 \\
\hline November & 0.08 & 0.33 \\
\hline December & 0.001 & 0.99 \\
\hline DJF & 0.001 & 0.99 \\
\hline MAM & -0.13 & 0.14 \\
\hline JJA & 0.006 & 0.95 \\
\hline SON & -0.01 & 0.90 \\
\hline Annual & -0.06 & 0.50 \\
\hline
\end{tabular}


The most interesting and highest significance was observed for the month of June, when precipitation shows a remarkably significant increasing trend over the complete time period (Table 6) and over the majority of arable land (Figure $21 \mathrm{~A} \& 21 \mathrm{~B}$ ). But, despite the highly significant June month precipitation trend, JJA season has shown no significant trend.
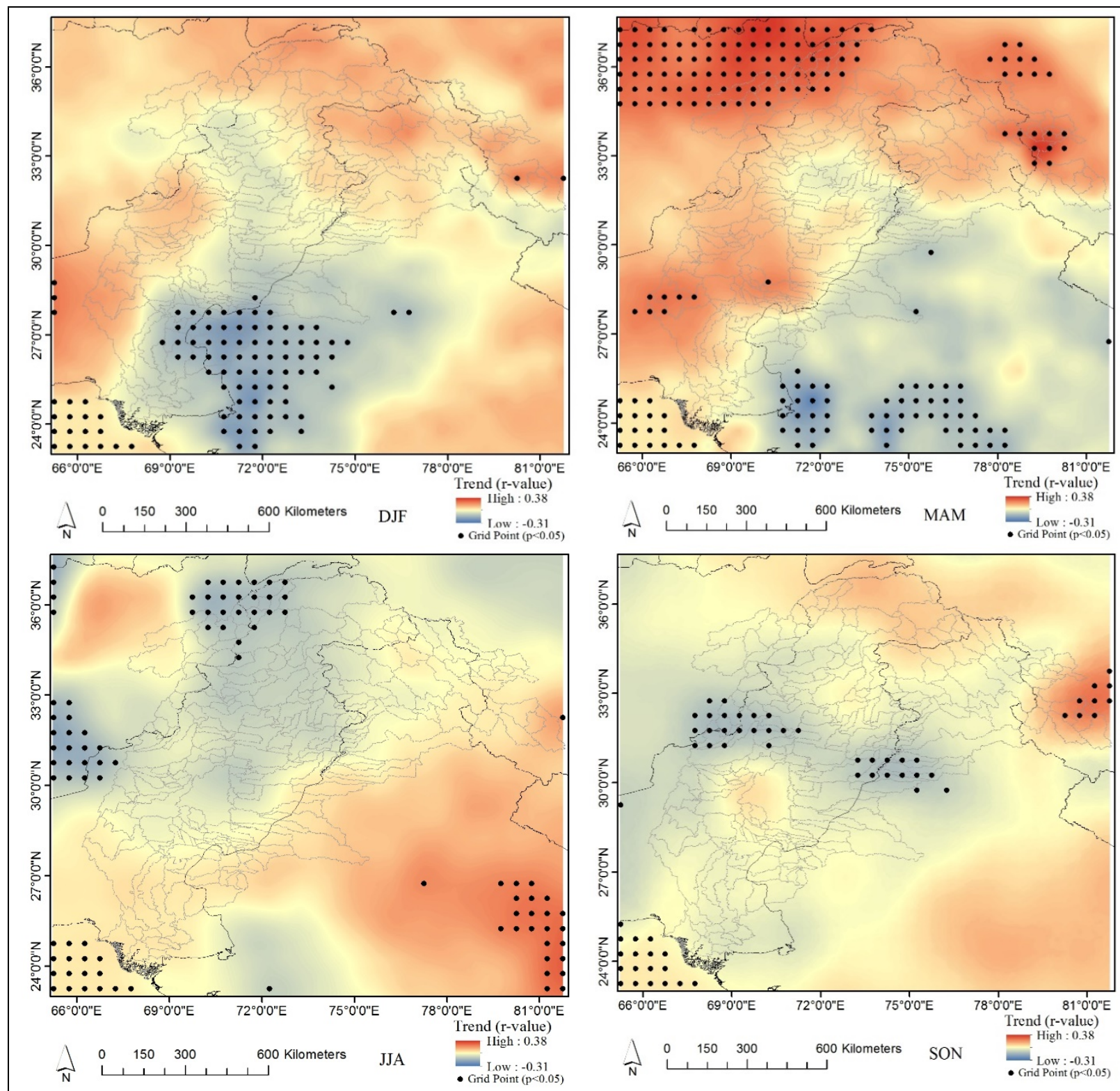

Figure 13. Spatial trend map of PREC/L seasonal precipitation 
Findings from the PREC/L dataset are consistent with those of the MERRA-2 dataset. Maps produced from both datasets lead to similar conclusions, namely that the majority of changing precipitation trends (annual, seasonal and monthly) have occurred at the boundary or the neighborhood regions of the Indus Basin. The month of June is an exception, with a significant increasing trend within the boundary limits of the Indus Basin.

\subsection{MERRA-2 Air Temperature}

Monthly, seasonal and annual trend test conducted on spatially averaged air temperature data available at vertical height of $2 \mathrm{~m}$ (Table 7) and $10 \mathrm{~m}$ (Table 8) give coherent and consistent results that imply no significant change in air temperature trends, except the month of October which shows a significantly increasing trend at both $2 \mathrm{~m}$ and $10 \mathrm{~m}$ from surface.

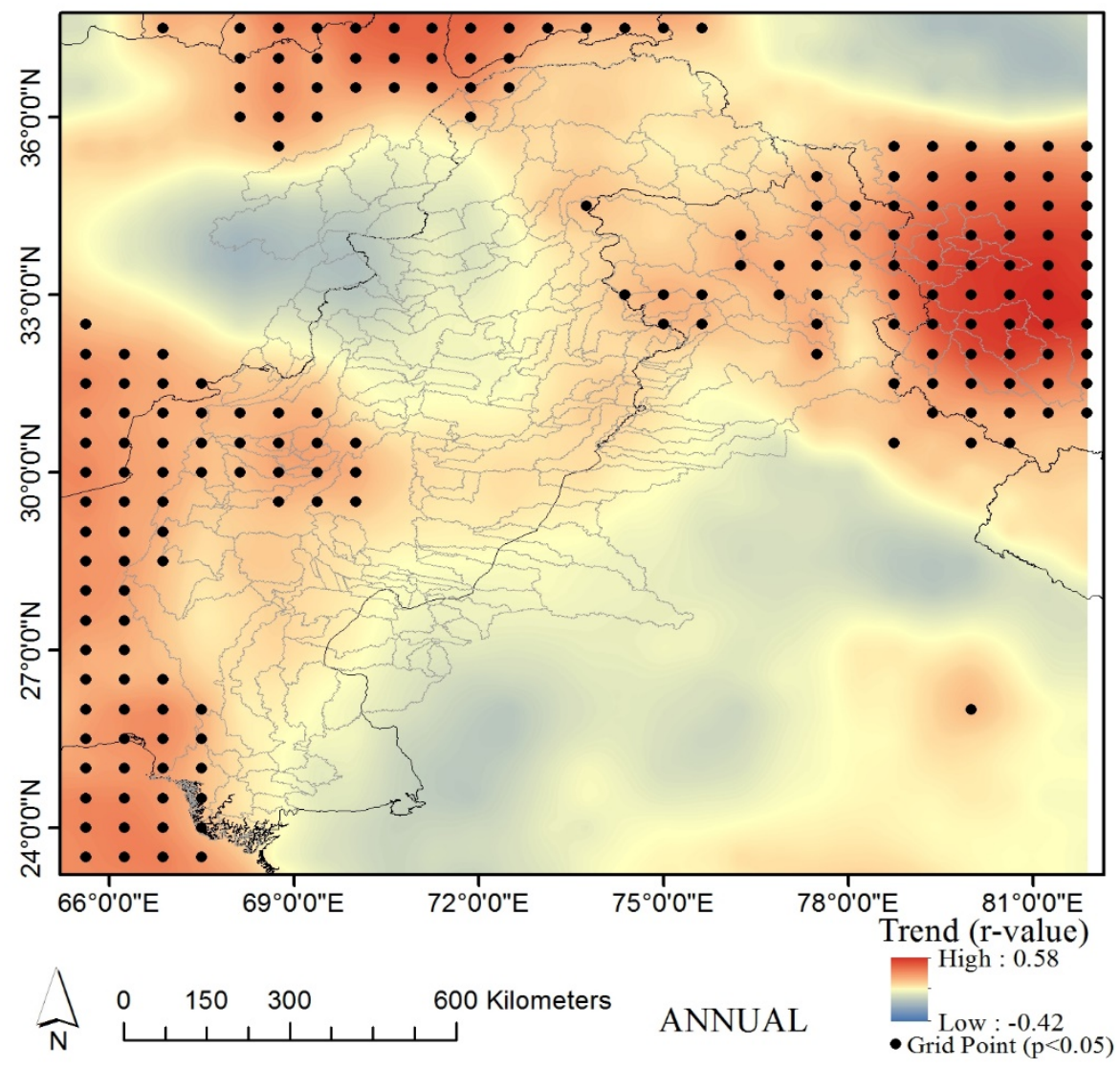

Figure 14 Spatial trend map of annual air temperature at $2 \mathrm{~m}$ 
Table 7. Monthly, seasonal and annual trends of spatially averaged MERRA-2 air temperature at $2 \mathrm{~m}$

Asterisk $(*)$ symbol shows time interval with significant $p$-value $(\mathrm{p}<0.05)$

\begin{tabular}{|l|l|l|}
\hline Time Interval & $\mathrm{r}$ & $\mathrm{p}$ \\
\hline January & 0.07 & 0.53 \\
\hline February & 0.13 & 0.26 \\
\hline March & 0.21 & 0.06 \\
\hline April & 0.10 & 0.37 \\
\hline May & 0.12 & 0.30 \\
\hline June & -0.08 & 0.47 \\
\hline July & -0.11 & 0.35 \\
\hline August & -0.02 & 0.84 \\
\hline September & 0.001 & 1.00 \\
\hline October* & 0.26 & 0.02 \\
\hline November & 0.12 & 0.30 \\
\hline December & -0.007 & 0.96 \\
\hline DJF & 0.12 & 0.29 \\
\hline MAM & 0.21 & 0.06 \\
\hline JJA & -0.11 & 0.32 \\
\hline SON & 0.19 & 0.09 \\
\hline Annual & 0.18 & 0.11 \\
\hline & & \\
\hline
\end{tabular}


Table 8. Monthly, seasonal and annual trends of spatially averaged MERRA-2 air temperature at $10 \mathrm{~m}$

Asterisk (*) symbol shows time interval with significant $\mathrm{p}$-value $(\mathrm{p}<0.05)$

\begin{tabular}{|l|l|l|}
\hline Time Interval & $\mathrm{r}$ & $\mathrm{p}$ \\
\hline January & 0.10 & 0.41 \\
\hline February & 0.13 & 0.26 \\
\hline March & 0.22 & 0.05 \\
\hline April & 0.09 & 0.44 \\
\hline May & 0.12 & 0.29 \\
\hline June & -0.10 & 0.38 \\
\hline July & -0.10 & 0.37 \\
\hline August & -0.03 & 0.82 \\
\hline September & 0.004 & 0.98 \\
\hline October* & 0.26 & 0.02 \\
\hline November & 0.09 & 0.44 \\
\hline December & 0.01 & 0.90 \\
\hline DJF & 0.14 & 0.22 \\
\hline MAM & 0.21 & 0.06 \\
\hline JJA & -0.12 & 0.29 \\
\hline SON & 0.17 & 0.12 \\
\hline Annual & 0.19 & 0.09 \\
\hline & & \\
\hline
\end{tabular}


Maps of the trends show hotspots, which have significantly changing air temperature trends (Figure $14 \& 15$ annual; Figure $22 \& 24$ seasonal; Figure 23A, 23B, 25A \& 25B monthly for air temperature at $2 \mathrm{~m} \& 10 \mathrm{~m}$ respectively). March and October month maps show extensive areas over which a significant increasing trend is observed.

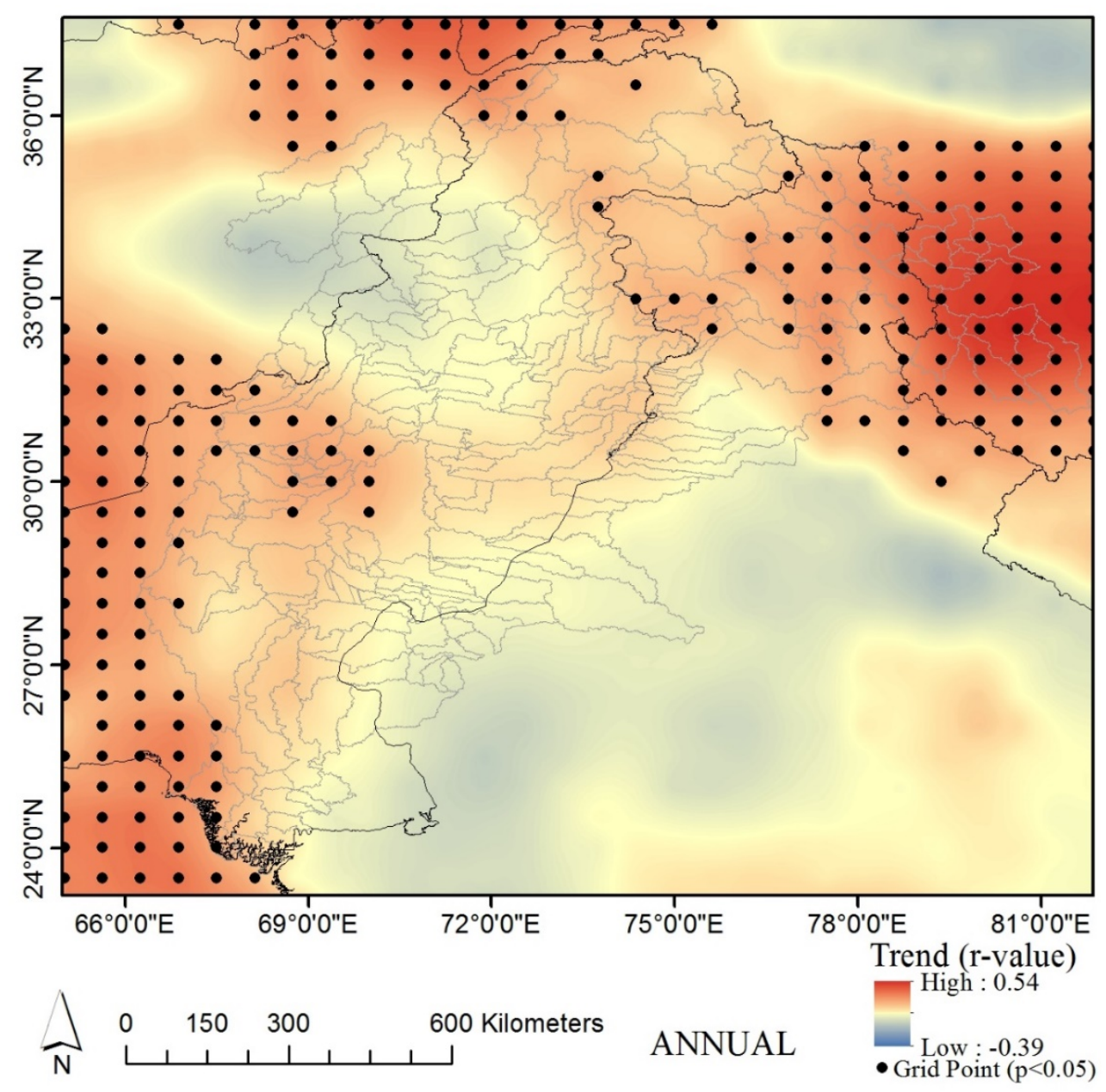

Figure 15 Spatial trend map of annual air temperature at $10 \mathrm{~m}$

\subsection{MODIS Snow Cover}

Trend analysis on MODIS snow cover data does not show any statistically significant results for any temporal resolution (monthly, seasonal and annual) (Table 9). Trend analysis on 
available data indicates that snow cover extent has not significantly changed over the Indus Basin region.

Table 9. Monthly, seasonal and annual trends of spatially averaged MODIS snow cover extent

\begin{tabular}{|l|l|l|}
\hline Time Interval & $\mathrm{r}$ & $\mathrm{p}$ \\
\hline January & -0.38 & 0.06 \\
\hline February & -0.17 & 0.45 \\
\hline March & -0.01 & 1.00 \\
\hline April & -0.08 & 0.75 \\
\hline May & -0.06 & 0.83 \\
\hline June & -0.09 & 0.67 \\
\hline July & -0.18 & 0.38 \\
\hline August & 0.06 & 0.83 \\
\hline September & 0.12 & 0.59 \\
\hline October & -0.34 & 0.10 \\
\hline November & 0.34 & 0.10 \\
\hline December & -0.01 & 0.67 \\
\hline DJF & -0.45 & 0.06 \\
\hline MAM & 0.03 & 0.91 \\
\hline JJA & -0.18 & 0.38 \\
\hline SON & 0.06 & 0.83 \\
\hline Annual & -0.23 & 0.28 \\
\hline
\end{tabular}




\subsection{Combined Overview on Hydro-climatic Parameters}

In order to understand the uncertainty and variability of hydro-climatic parameters, a comprehensive trend test was conducted on precipitation, air temperature and snow cover extent to evaluate changes in the respective parameters over monthly, seasonal and annual scales. All three parameters showed no evidence of changing trends in the last several decades, (depending upon the time period over which data are available). However, there have been some exceptions where significant trends have been found such as the month of June, which has shown a significant increasing trend in precipitation, and the month of October, which exhibits a significant increasing trend in air temperature. Despite significant change in the June precipitation and October air temperature, the corresponding seasonal and annual changes are negligible. Thus, the hydroclimatic system of the Indus Basin can be assumed to be unchanged.

\subsection{Current and Prospective Status of Groundwater in Punjab}

Although the hydro-climatic system appears to be stable, the Punjab (India) region has been under continuous water stress for an extended period of time. This water stress suggests an additional factor influences the natural system. Considering this vibrant behavior, Punjab (India) region was selected for groundwater analysis. We believe that this additional factor is the introduction of paddy crop into the traditional cropping system, which has changed the water demand, while supply remain almost constant. The water requirement for paddy crop is $1200-1400$ $\mathrm{mm}$, which is far more than a complete cropping rotation (wheat-maize:- traditionally implemented cropping rotation in Punjab). Therefore, the implementation of water intensive crops in both seasons (kharif \& rabi; paddy-wheat) has escalated the water demand and forced to rely on groundwater resources. This overwhelming demand has resulted in continuous water stress for the 
region for last decades and continuous withdrawal has brought the region to become a complete water scarce. This situation was first surfaced in the early 1970's, when an exponential increase in paddy's area led to increase in water demand which had fulfilled by intensive groundwater extraction and that, eventually surpassed the annual groundwater recharge in following decade.

A comprehensive study was conducted out on aquifers to quantify the fresh groundwater resources and its availability for agricultural use. Trend analysis on GRACE data indicated a highly significant decline in groundwater $(\mathrm{r}$ value $=-0.79)$, implying over-exploitation of groundwater storage; far more than the recharge. The current rate of groundwater depletion in the region suggests toward the inevitability of no fresh groundwater scenario, and that, the region will have depleted all the useable fresh groundwater resources in the future.

\section{$\underline{\text { Assumptions }}$}

A set of assumptions were made to determine the timeline for which a particular aquifer would no longer sustain agriculture:

1) Despite the paddy-wheat cropping pattern, only the paddy crop is considered for this study. This choice was made due to the introduction of paddy into mainstream cropping rotation during the Green Revolution. We suspect this addition is the main cause of groundwater exploitation and depletion and we wanted to investigate the core influence of paddy cultivation on groundwater resources.

2) The full potential of available surface water and fresh groundwater is considered and assumed to be focused toward agricultural purposes only (paddy crop).

3) Aquifer availability and groundwater recharge is considered as a proportion to paddy area for the particular year. 
Based on available aquifer mapping data, the aquifers up-to $300 \mathrm{~m}$ below ground level have already been tapped in Punjab. The following timelines were generated using spatially averaged aquifer data over Punjab: -

1) The aquifer I along with full potential of surface water and dynamic ground water resources becomes insufficient to meet the water requirement of paddy crop with respect to area under paddy cultivation in between year 2008-09 (Figure 16).

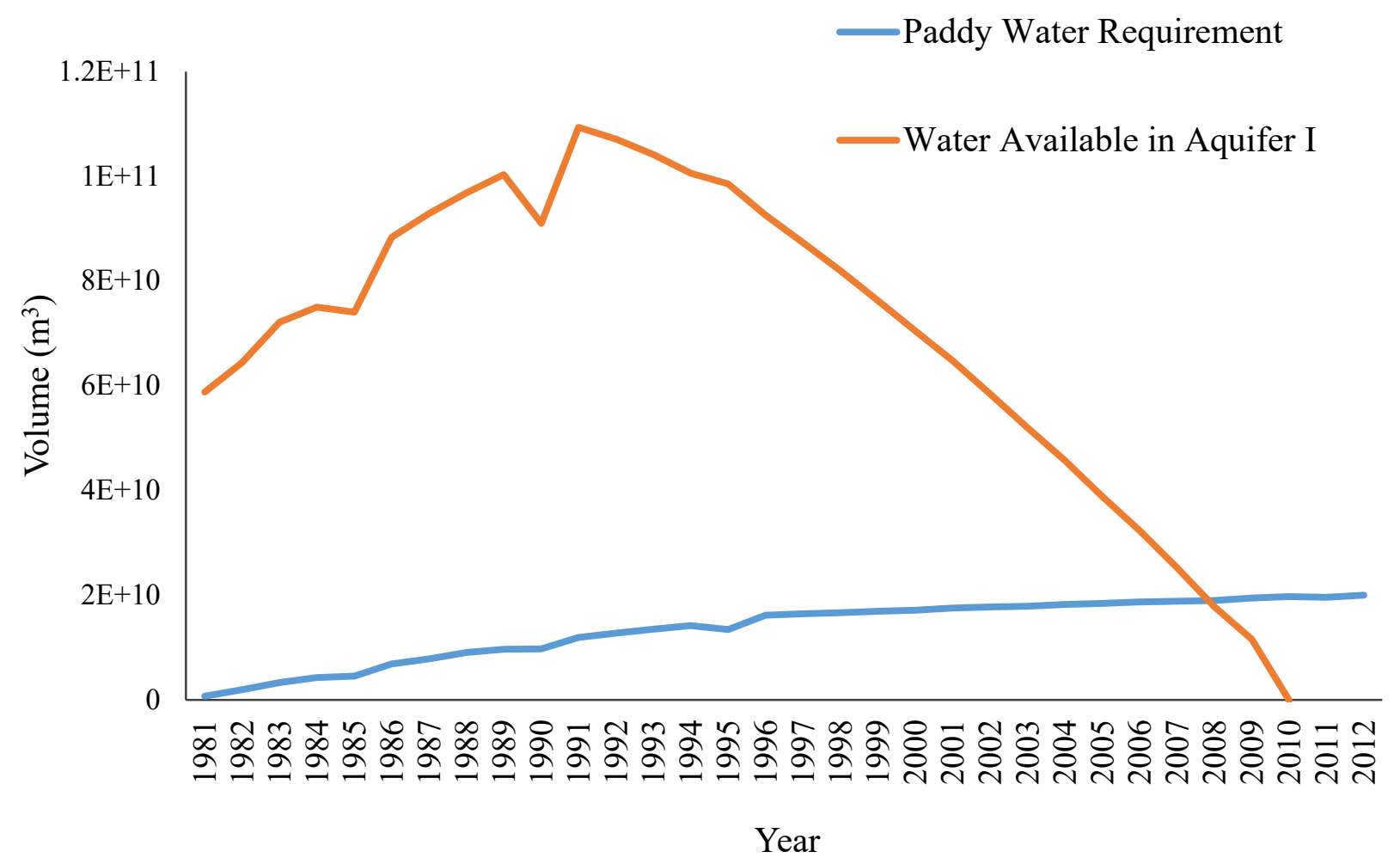

Figure 16. Timeline for Aquifer I with respect to Paddy Water Requirement

2) The second tier of aquifers i.e. aquifer II would only be sufficient until time period 202021 (Figure 17). 


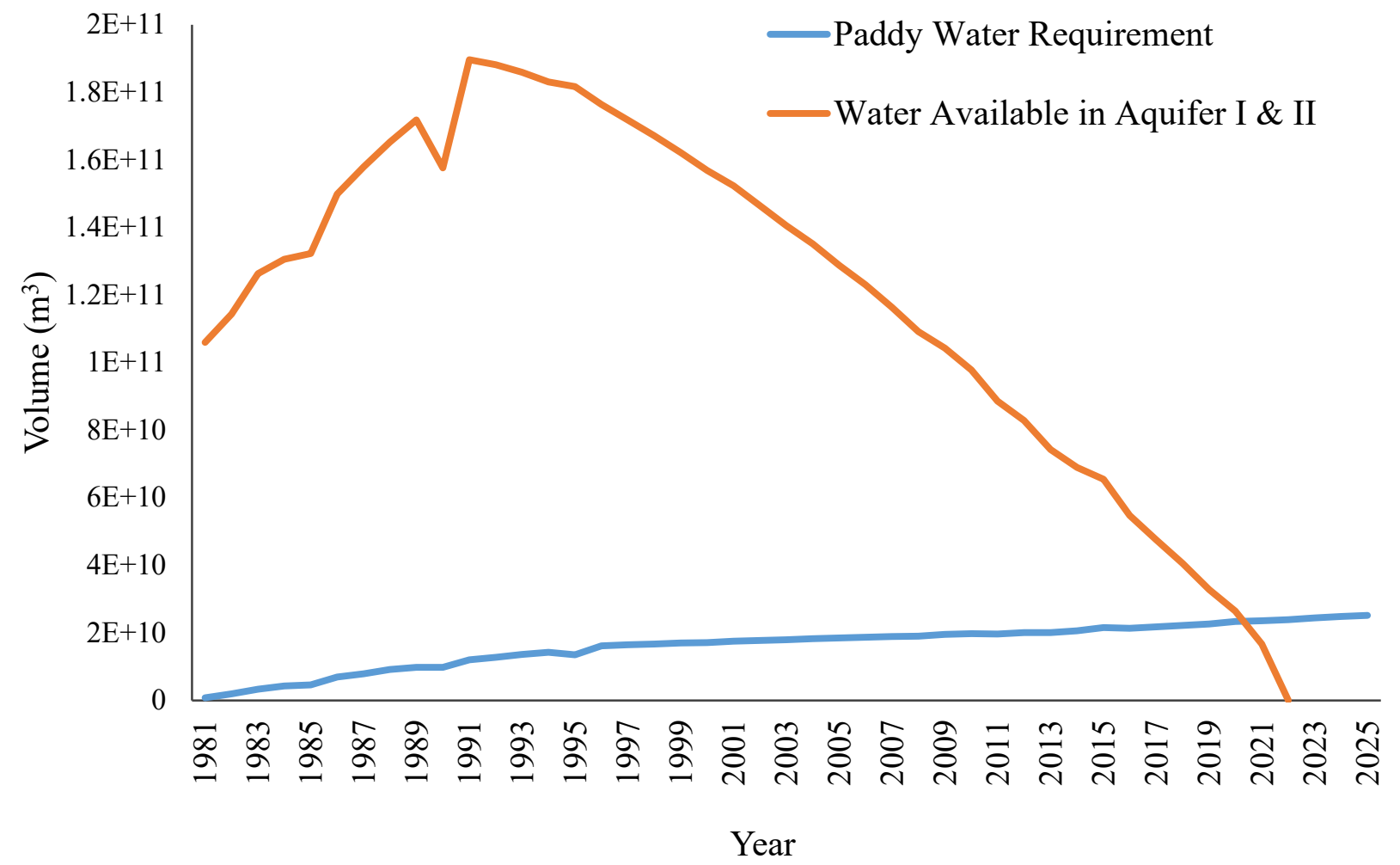

Figure 17. Timeline for Aquifer II with respect to Paddy Water Requirement

3) With respect to the increase in area under paddy crop and to meet the associated water requirement, aquifer III would be the last groundwater resource. It is estimated that water requirement will surpass the total water available from accumulative contribution of surface water, dynamic groundwater resources, aquifer I, aquifer II and aquifer III in period between 2031-33. This trend suggested an imminent desertification of Punjab (Figure 18). 


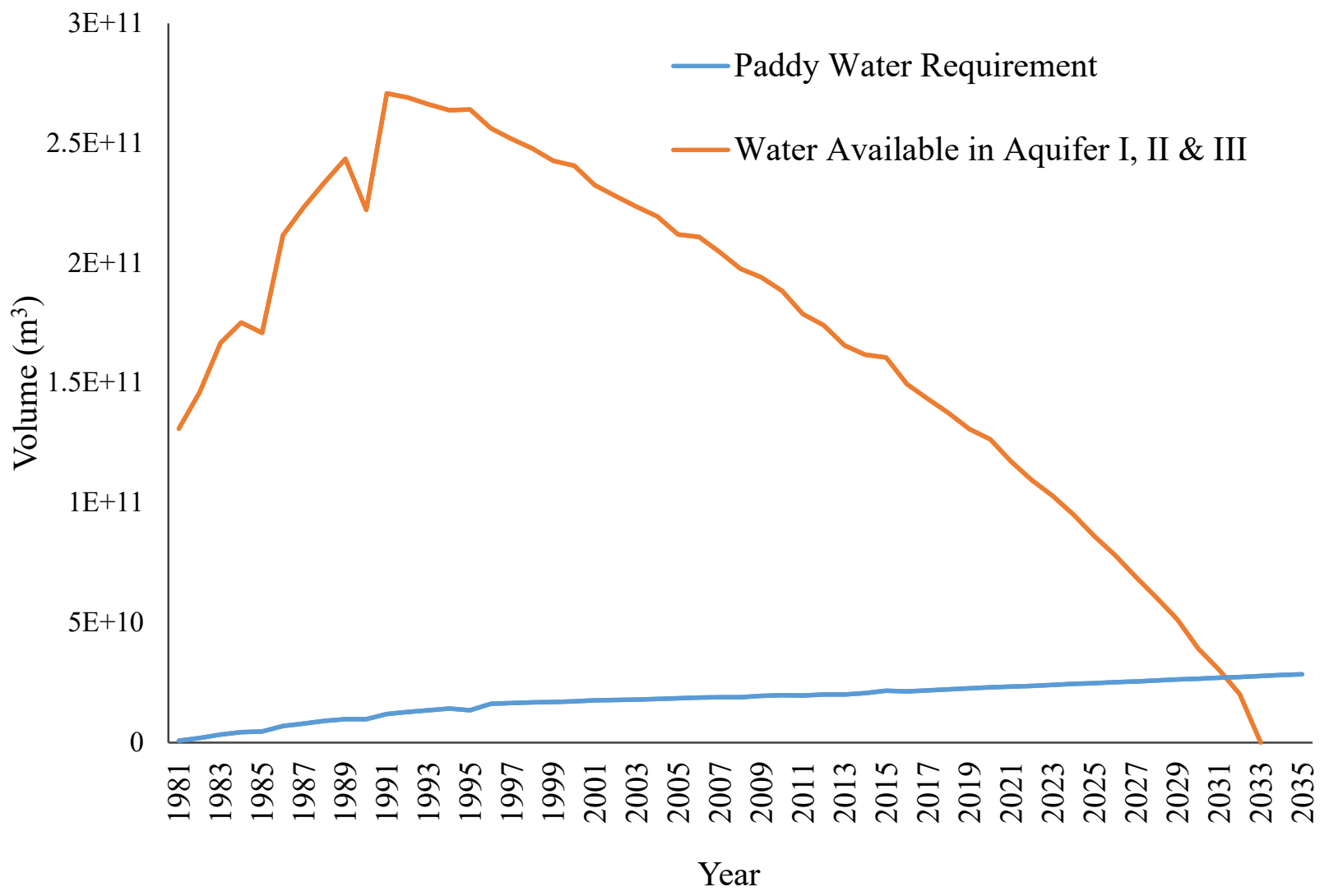

Figure 18. Timeline for Aquifer III with respect to Paddy Water Requirement 


\section{CHAPTER 6: SUMMARY AND CONCLUSION}

\subsection{Summary}

The following observations and conclusions were generated through this study:

1) Among hydro-climatic parameters, precipitation and temperature have direct influence on agriculture in terms of crop production and yield. In this study, trend analysis was conducted on precipitation and air temperature to investigate the spatial and temporal variability over the Indus Basin. This did not yield a significant temporal trend, but the spatial trends demonstrated the nonuniform distribution of precipitation. The consistency in results derived from PREC/L dataset that provided a long term view of precipitation trends, combined with the MERRA-2 dataset has clarified the ambiguity in the literature. In addition, MERRA-2 precipitation dataset provided insights regarding total precipitation components indicating strong spatial variation in large scale precipitation and in convective precipitation. A significant increasing trend was found in annual and JJA seasonal large scale precipitation, but this trend did not contribute any changes in total precipitation over the Indus Basin and thus, the annual and seasonal trends of total precipitation were insignificant.

Air temperature data was also similarly analyzed at $2 \mathrm{~m}$ and $10 \mathrm{~m}$ vertical height and yielded no significant annual and seasonal trends. Both air temperature and precipitation showed no annual or seasonal trends except some monthly trends.

The trend analysis on snow cover extent gave inconclusive results, however a nonsignificant decreasing trend was observed at the annual scale.

2) Groundwater depletion is major concern in Punjab. To understand the severity of the problem, aquifer characteristics were assessed to quantify groundwater resources. Considering 
paddy as a sole crop grown annually in the region, a timeline was generated to estimate when groundwater provided by certain aquifer would be insufficient to meet the demand of paddy water requirement over that region. It is concluded that with the recent trend in agriculture practices and groundwater depletion, the groundwater resources up to $300 \mathrm{~m}$ would be exhausted in the next 1015 years.

\subsection{What Could be the Ideal Agricultural Scenario in the Indus}

\section{Basin?}

Agriculture is the major user of water resources in the Indus Basin. As precipitation and temperature showed no trend, there wouldn't be any water stress presuming water demand and water utilization practices remained unchanged.

The average annual rainfall in the Punjab region is $810 \mathrm{~mm}$, and the cumulative water requirement of conventional cropping pattern (wheat and maize) is around $1000 \mathrm{~mm}$. With an intensive network of rivers, the gap between precipitation and water demand $(190 \mathrm{~mm})$ could be easily delivered without adding stress to groundwater resources, which makes conventional cropping pattern quintessential. It was possible to sustain agriculture on rain-fed system with limited surface and sub-surface water availability (through canals and shallow groundwater resources).

Even if wheat and maize area had cumulatively increased at the same pace as paddy area, groundwater decline wouldn't be an issue. As cumulative water requirement for wheat and maize is around $70 \%$ of the water requirement for paddy crop. 


\subsection{Future Work}

\subsubsection{Scope for Future Exploratory Studies on Hydroclimatic Parameters}

Due to the short period of data, a statistical analysis on a few parameters like snow cover did not give conclusive results. This opens a window of opportunity in coming years to repeat these experiments. This study also lays the groundwork for applying these approaches to similar agricultural basins around the world.

\subsubsection{Trade-off Between Food Security and Water Security}

It is evident that the main cause of groundwater depletion is anthropogenic usage rather than natural variability. The need for fulfilling the food demands of a growing population along with ensuring socio-economic status and achieving self-sustaining food security within the basin has put groundwater resources under enormous stress. During the Green Revolution in the 1960s, Punjab achieved the title of "granary of India" by ensuring self-sufficiency in terms of food grain production, with surplus for export. However, this food security was achieved and ensured through intensive use of high yielding and genetically modified crop varieties, use of chemical fertilizers, assured irrigation and expansion of area under cultivation, which is further supported by mechanization. In addition, paddy crop was introduced during that era, which have brought unprecedented consequences in recent time. The paddy-wheat cropping rotation has replaced the conventional cropping pattern of wheat-maize in Punjab due to continuous financial support and promotion by government along with assured pricing. The high water requirement of paddy and exponential rise in its area has led to excessive groundwater withdrawal, and consequently, has brought Punjab to the brink of becoming water abundant to water scarce. 
This entire study provides an opportunity to look forward to how the trade-off prioritizing food security over water security has costed the region. A recent study by Davis et al. (2018) has shed light on the need of alternative to paddy crop. It is found that rice is the least water efficient cereal crop in the context of producing key nutrients, and if any other cereal crop having lower irrigation water footprint is used as replacement to rice, it can decrease water demand by $33 \%$ and increases the percentage of key nutrient as well. Thus, this study provide a platform for future studies focusing on nutritional security along with water and food security. 


\section{CHAPTER 7: BIBLIOGRAPHY}

Aeschbach-Hertig, W. and Gleeson, T. (2012). "Regional strategies for the accelerating global problem of groundwater depletion." Nature Geoscience, 5(12), 853.

Ahmad, M. U. D., Turral, H., and Nazeer, A. (2009). "Diagnosing irrigation performance and water productivity through satellite remote sensing and secondary data in a large irrigation system of Pakistan." Agricultural Water Management, 96(4), 551-564.

Akhtar, M., Ahmad, N., and Booij, M. J. (2008). "The impact of climate change on the water resources of Hindukush-Karakorum-Himalaya region under different glacier coverage scenarios." Journal of hydrology, 355(1-4), 148-163.

Archer D. R., Forsythe N, Fowler H. J., and Shah S. M. (2010). "Sustainability of water resources management in the Indus Basin under changing climatic and socio economic conditions." Hydrol Earth Syst Sci, 14:1669-1680.

Archer, D. R. (2003). "Contrasting hydrological regimes in the upper Indus basin." Journal of Hydrology, 274, 198-210.

Archer, D. R., and Fowler, H. J. (2004). "Spatial and temporal variations in precipitation in the Upper Indus Basin, global teleconnections and hydrological implications." Hydrology and Earth system. Sciences Discussions, European Geosciences Union, 8 (1), pp.47-61.

Bastiaanssen, W. G., Ahmad, M. U. D., and Chemin, Y. (2002). "Satellite surveillance of evaporative depletion across the Indus Basin." Water Resources Research, 38(12), 9-1. 
Bhutiyani, M. R., Kale, V. S., and Pawar, N. J. (2007). "Long-term trends in maximum, minimum and mean annual air temperatures across the Northwestern Himalaya during the twentieth century." Climatic Change, 85(1-2), 159-177.

Cheema, M. J. M., Immerzeel, W. W., and Bastiaanssen, W. G. M. (2014). "Spatial quantification of groundwater abstraction in the irrigated Indus basin." Groundwater, 52(1), 25-36.

Chen, J., Li, J., Zhang, Z., and Ni, S. (2014). "Long-term groundwater variations in Northwest India from satellite gravity measurements." Global and Planetary Change, 116, 130-138.

Chopra, R. P. S., and Krishan, G. (2014). "Assessment of Ground Water Quality in Punjab., India." Earth Science \& Climatic Change, 5(10).

Dahri, Z. H., Ludwig, F., Moors, E., Ahmad, B., Khan, A. and Kabat, P. (2016). "An appraisal of precipitation distribution in the high altitude catchments of the Indus basin." Science of the Total Environment, 548-549, 289-306.

Davis, K. F., Chiarelli, D. D., Rulli, M. C., Chhatre, A., Richter, B., Singh, D., and DeFries, R. (2018). "Alternative cereals can improve water use and nutrient supply in India." Science advances, 4(7), eaao1108.

Forsyethe, N., Fowler, H. J., Kilsby, C. G., and Archer D. R. (2012). "Opportunities from remote sensing for supporting water resources management in village/valley scale catchments in the upper Indus basin." Water Resource Management, 26(4), 845-871.

Fowler, H. J. and Archer, D. R. (2006). "Conflicting signals of climate change in the Upper Indus Basin." Journal of Climate, 19, 4276-4293. 
Gadgil, S., and Kumar, K. R. (2006). "The Asian monsoon- agriculture and economy." In The Asian Monsoon, 651-683. Springer Berlin Heidelberg.

Grant, Discovery. (2013). "The Shadow Value of Groundwater in Punjab, India: An analysis in an Economy-Wide Context."

Hoekstra, A. Y., Mesfin M. M., Chapagain A. K., Mathews R. E., and Richter B. D. (2012). "Global monthly water scarcity: blue water footprints versus blue water availability." Plos One, 7(2), e32688.

Immerzeel W.W., Wanders N., Lutz A. F., Shea J. M. and Bierkens M. F. P. (2015). "Reconciling high-altitude precipitation in the upper Indus basin with glacier mass balances and runoff." Hydrology and Earth System Sciences, 19,4673-4687.

Immerzeel, W. W., Van Beek, L. P., and Bierkens, M. F. (2010). "Climate change will affect the Asian water towers." Science, 328(5984), 1382-1385.

Kaur, B., Sidhu, R. S., and Vatta, K. (2008). crop plans for sustainable water use in Punjab. Agricultural Economics, PAU, Ludhiana.

Khattak, M. S., Babel, M. S., and Sharif, M. (2011). "Hydro-meteorological trends in the upper Indus River basin in Pakistan." Climate research, 46(2), 103-119.

Krishan, G., Rao, M. S., Loyal, R. S., Lohani, A. K., Tuli, N. K., Takshi, K. S., Kumar, C. P., Semwal, P. and Kumar, S. (2014)). "Groundwater level analyses of Punjab, India: A quantitative approach." Octa Journal of Environmental Research, 2(3).

Kumar, N., and Jaswal, A. K. (2016). "Historical temporal variation in precipitation over Western Himalayan Region: 1857-2006." Journal of Mountain Science, 13(4), 672-681. 
Laghari, A. N., Vanham, D., and Rauch, W. (2012). "The Indus basin in the framework of current and future water resources management." Hydrology and Earth System Sciences, 16(4), 1063.

Madhura R. K., Krishnan R., Revadekar J. V., Mujumdar M. and Goswami B. N. (2015). "Changes in western disturbances over the western Himalayas in a warming environment." Climate Dynamic, 44 (3-4), 1157-1168.

Miehe, G. (1992). "Recent climate change in the Karakoram as indicated by vegetation features and geomorphological processes." Cultural Area Karakoram Newsletter 2.

Palazzi, E., Hardenberg, J.V. and Provenzale, A. (2013). "Precipitation in the Hindu-Kush Karakoram Himalaya: Observations and future scenarios." Journal of Geophysical Research: Atmospheres, 118, 85-100.

Palazzi, E., Hardenberg, J. V. and Terzago, S. (2015). "Precipitation in the Karakoram- Himalaya: a CMIP5 View." Climate Dynamics, 45:21-45.

PAU, Ludhiana. 2007. Package of Practices for Kharif Crops of Punjab.

PAU, Ludhiana. 2007-08. Package of Practices for Rabi Crops of Punjab.

Statistical Abstract of Punjab. (2005), Directorate of Economics and Statistics, Government of Punjab, Chandigarh.

Qureshi, A. S. 2011. "Water management in the Indus basin in Pakistan: challenges and opportunities." Mountain Research and Development, 31(3), 252-260. 
Qureshi, A. S., McCornick, P. G., Sarwar, A., \& Sharma, B. R. 2010. "Challenges and prospects of sustainable groundwater management in the Indus Basin, Pakistan. ." Water resources management, 24(8), 1551-1569.

Rodell, M., Velicogna, I., and Famiglietti, J. S. (2009). "Satellite-based estimates of groundwater depletion in India." Nature, 460(7258), 999.

Sharif M., Archer D. R., Fowler H. J. and Forsythe N. (2013). "Trends in timing and magnitude of flow in the Upper Indus Basin." Hydrology and Earth System Sciences, 17, 1503-1516.

Singh, R. B., and Sen Roy, S. (2002). "Climate variability and hydrological extremes in a Himalayan catchment." ERB and Northern European FRIEND Project 5 Conf., Slovakia.

Singh, S. (2002). "Contracting out solutions: Political economy of contract farming in the Indian Punjab." World Development, 30(9), 1621-1638.

Tiwari, V. M., Wahr, J., and Swenson, S. (2009). "Dwindling groundwater resources in northern India, from satellite gravity observations." Geophysical Research Letters, 36(18).

Wake, C.P. (1989). "Glaciochemical investigations as a tool to determine the spatial variation of snow variation of snow accumulation in the Central Karakoram, Northern Pakistan." Annals of Glaciology, 13, 279-284.

Young, G. J. and Hewitt, K. (1990). "Hydrology research in the Upper Indus Basin, Karakoram Himalaya Pakistan." IAHS Publ, 190, 139-152.

Yu, W., Yang, Y. C., Savitsky, A., Alford, D., Brown, C., Wescoat, J., Debowicz, D., and Robinson, S. (2013). The Indus basin of Pakistan: the Impacts of Climate Risks on Water and Agriculture. The World Bank. 


\section{CHAPTER 8: APPENDIX}
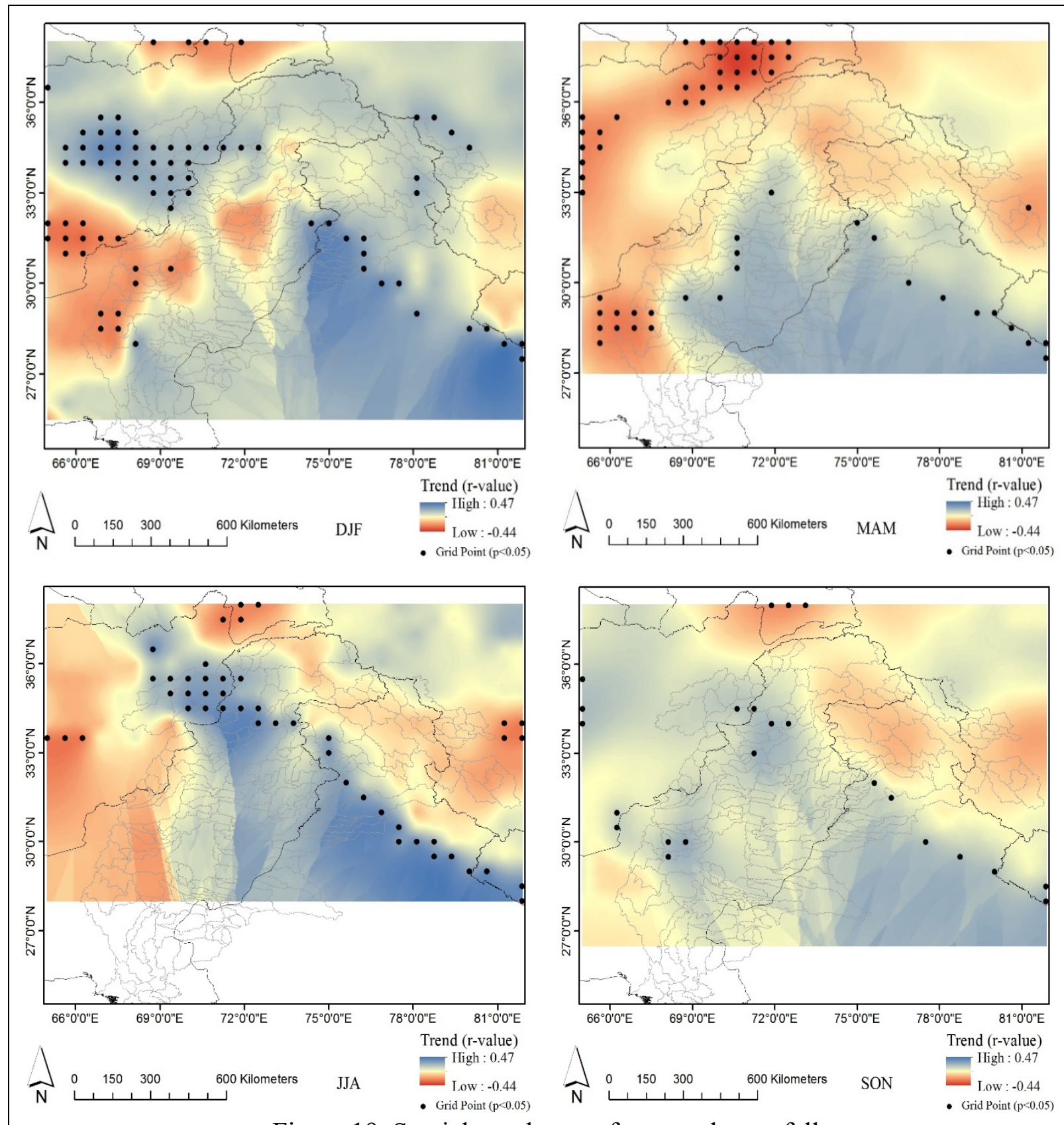

Figure 19. Spatial trend map of seasonal snowfall 

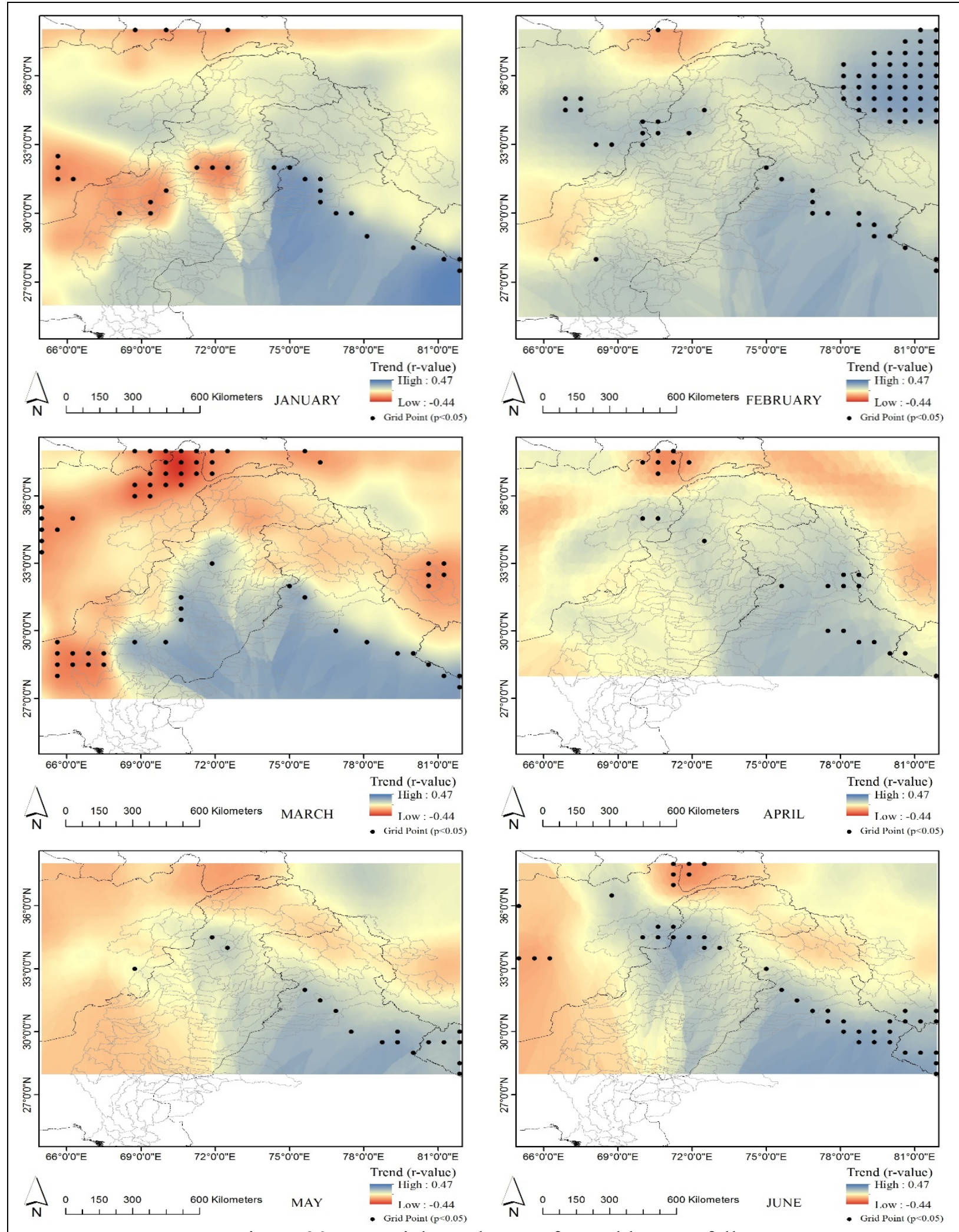

Figure 20A. Spatial trend map of monthly snowfall

(JAN-FEB-MAR-APR-MAY-JUNE) 

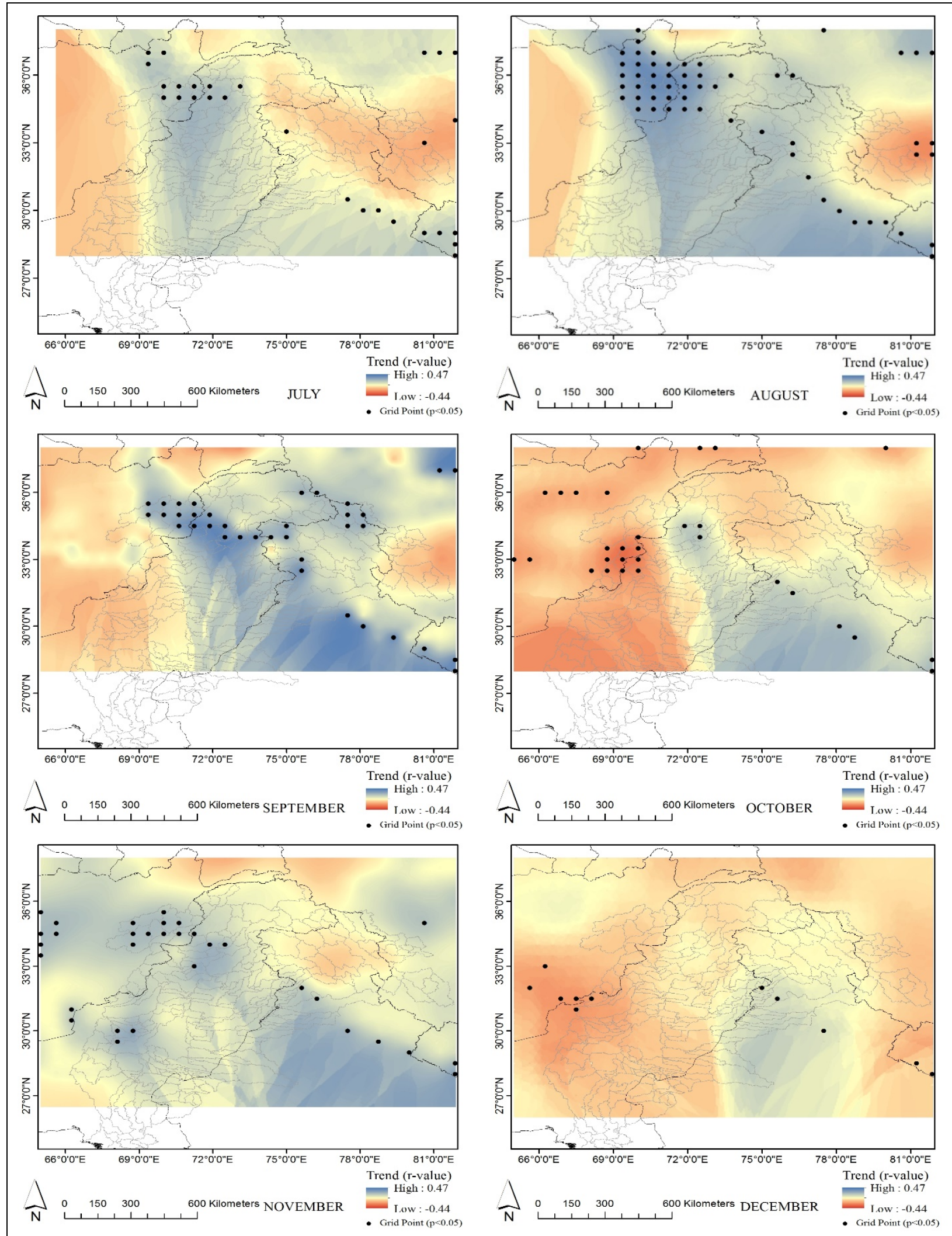

Figure 20B. Spatial trend map of monthly snowfall

\section{(JULY-AUG-SEPT-OCT-NOV-DEC)}



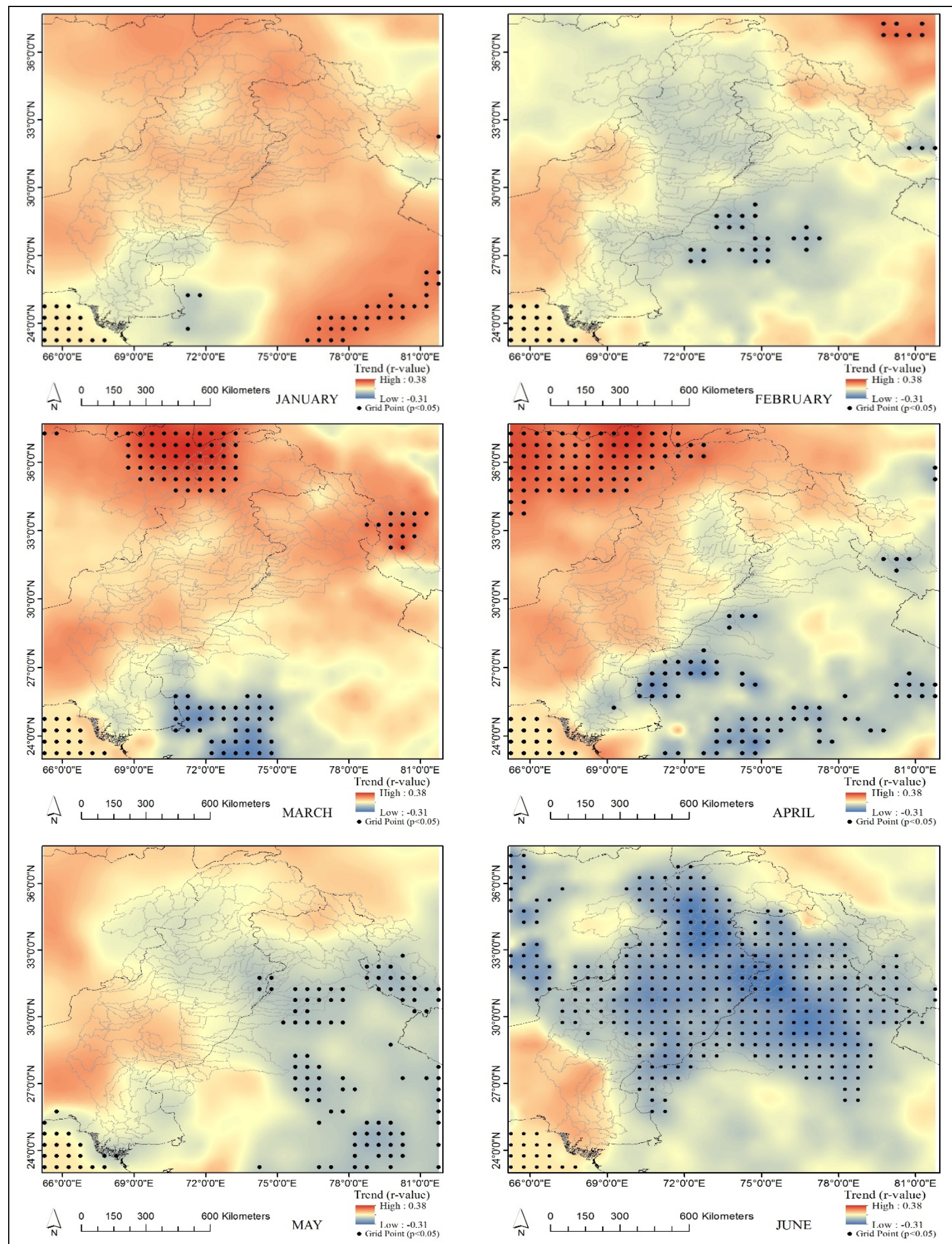

Figure 21A. Spatial trend map of PREC/L monthly precipitation (JAN-FEB-MAR-APR-MAY-JUNE) 

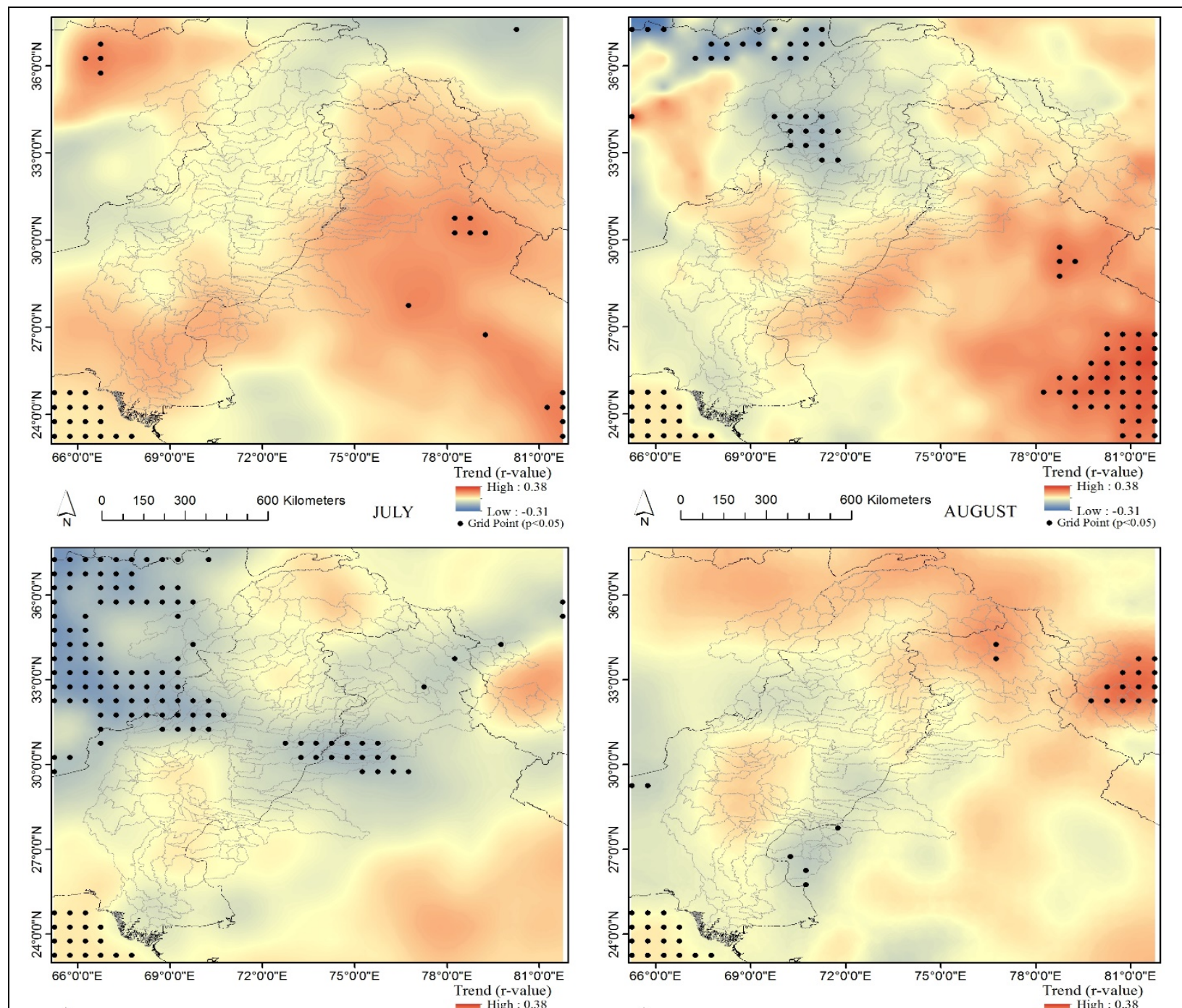

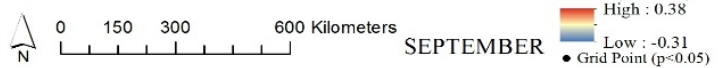
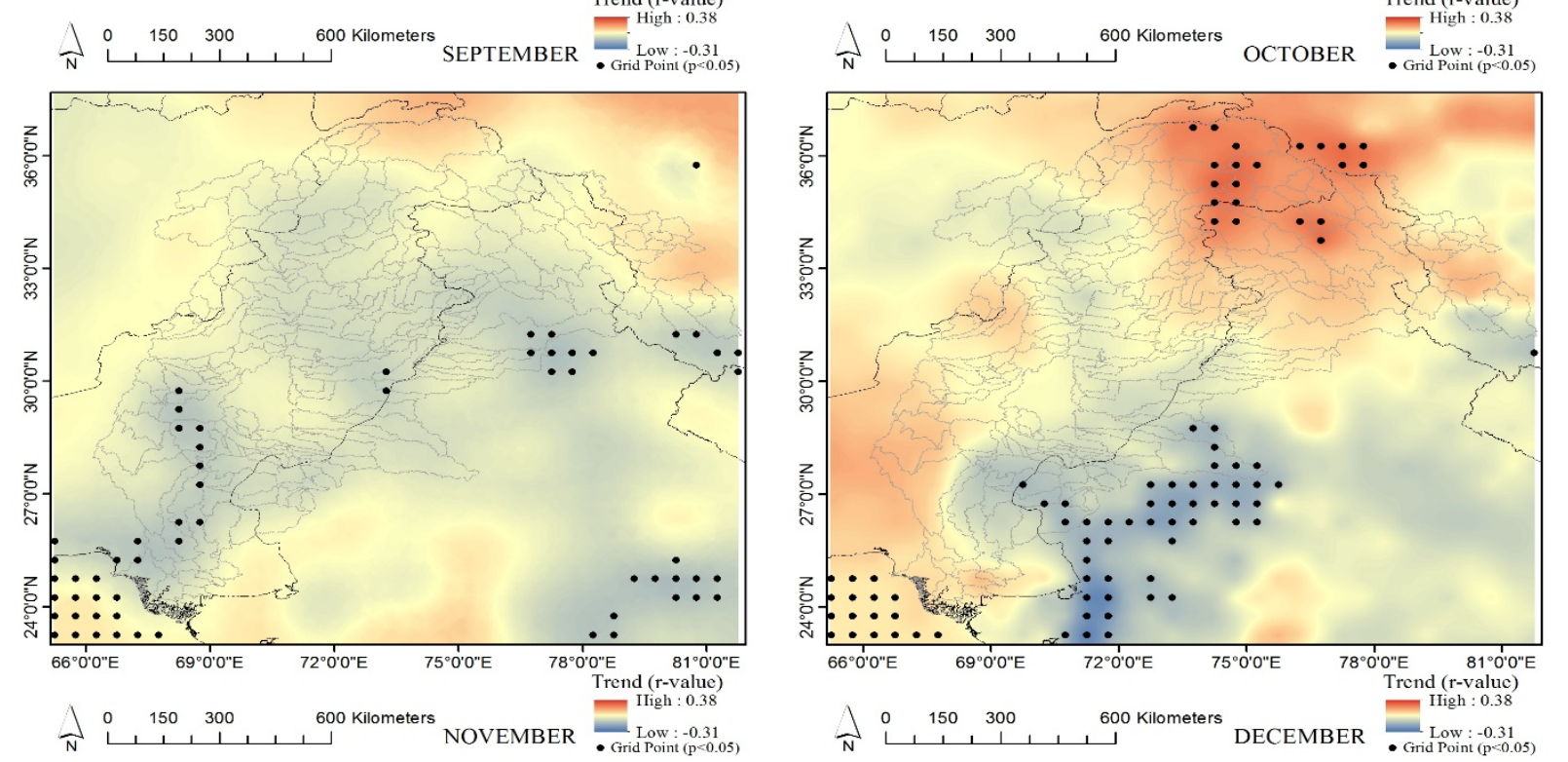

Figure 21B. Spatial trend map of PREC/L monthly precipitation (JULY-AUG-SEPT-OCT-NOV-DEC) 

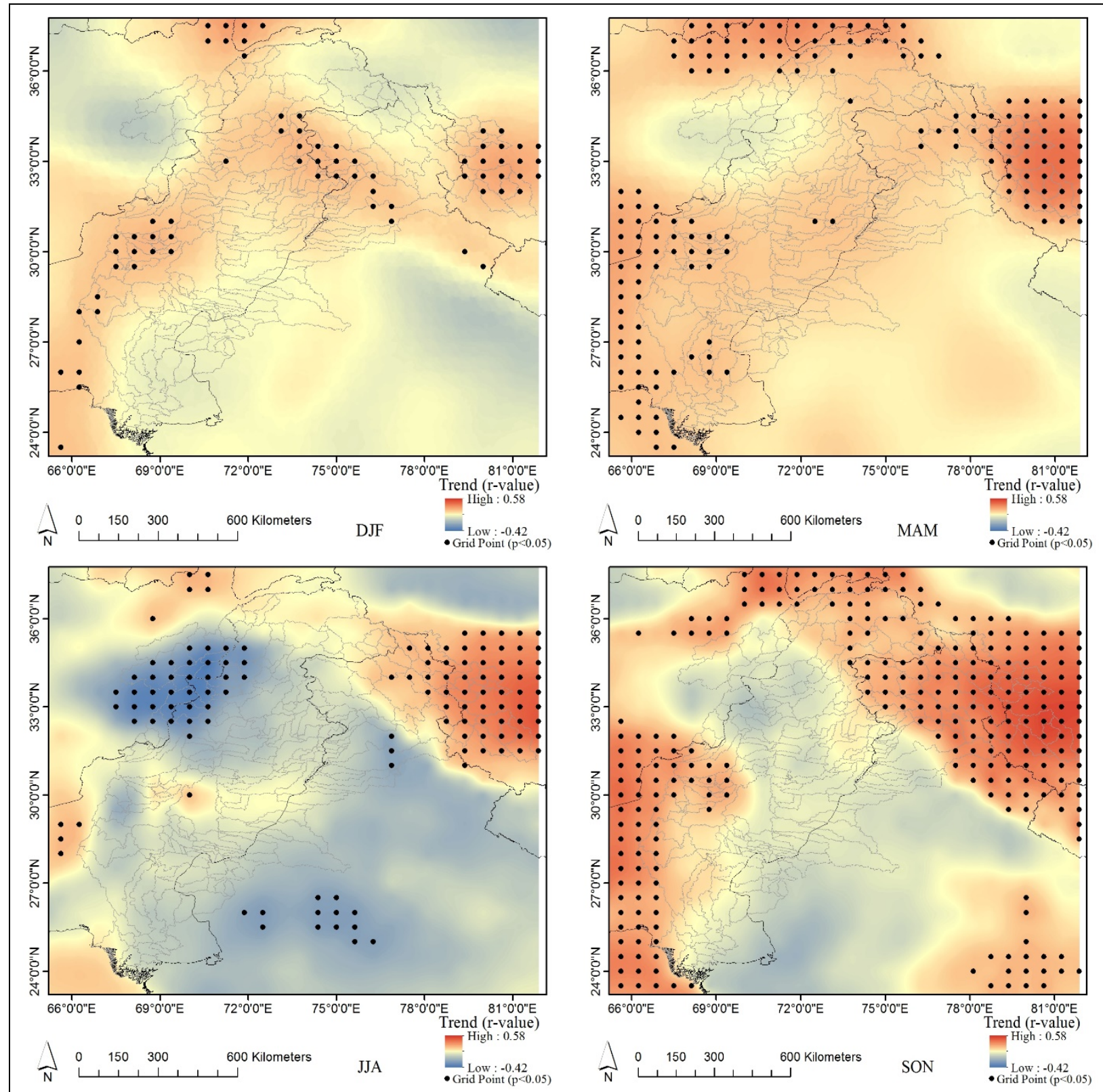

Figure 22. Spatial trend map of seasonal air temperature at $2 \mathrm{~m}$ 

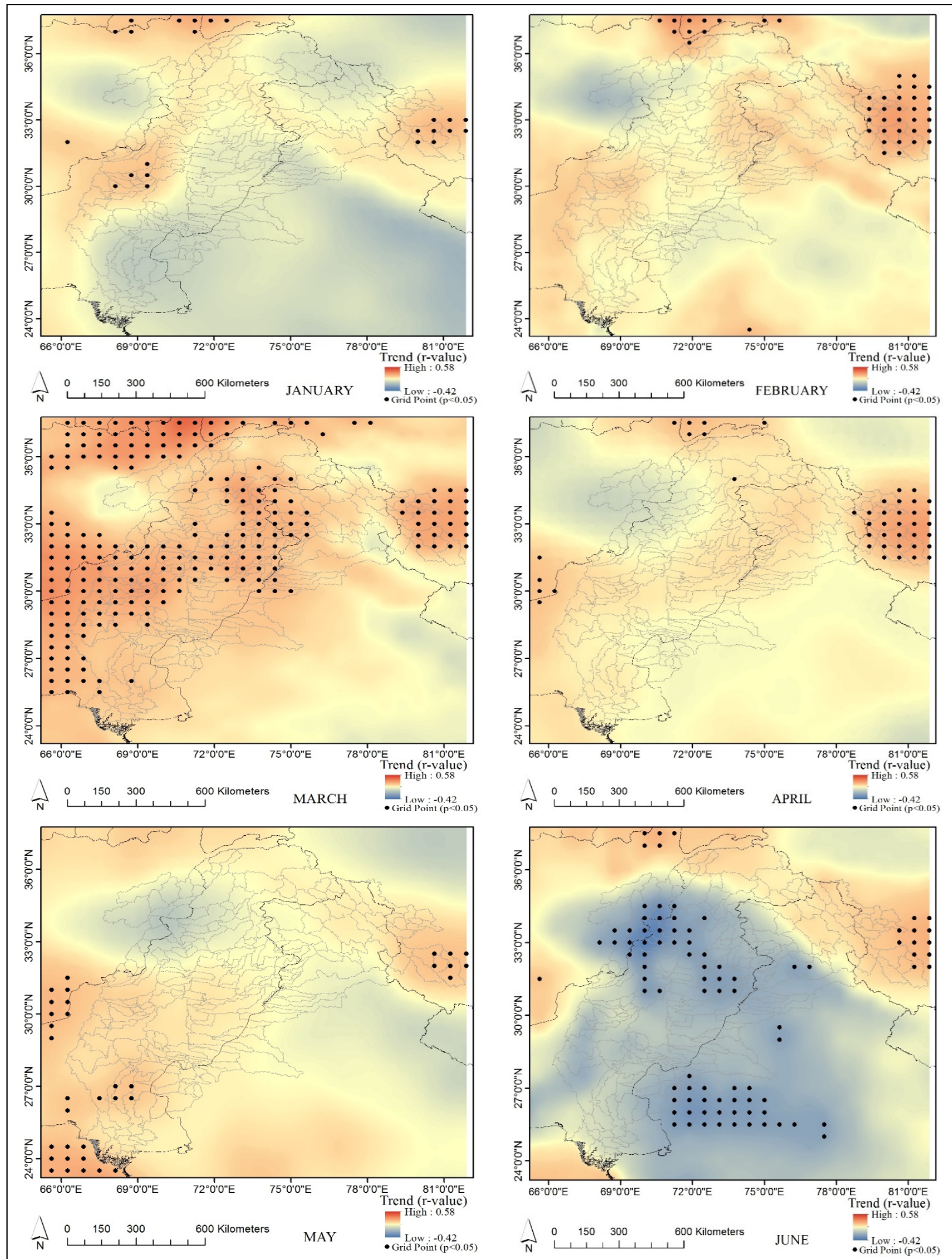

Figure 23A. Spatial trend map of monthly air temperature at $2 \mathrm{~m}$ (JAN-FEB-MAR-APR-MAY-JUNE) 

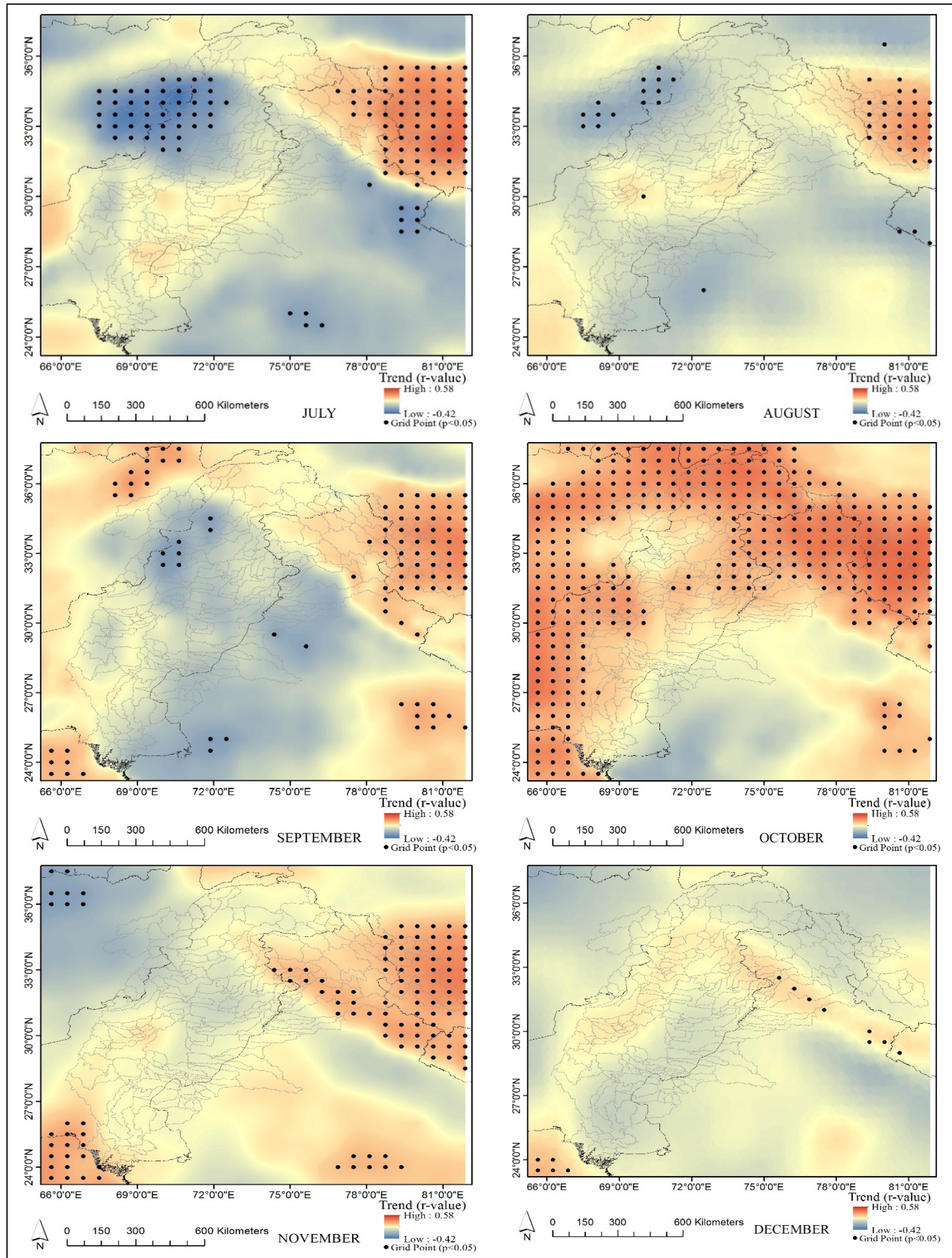

Figure 23B. Spatial trend map of monthly air temperature at $2 \mathrm{~m}$ (JULY-AUG-SEPT-OCT-NOV-DEC) 

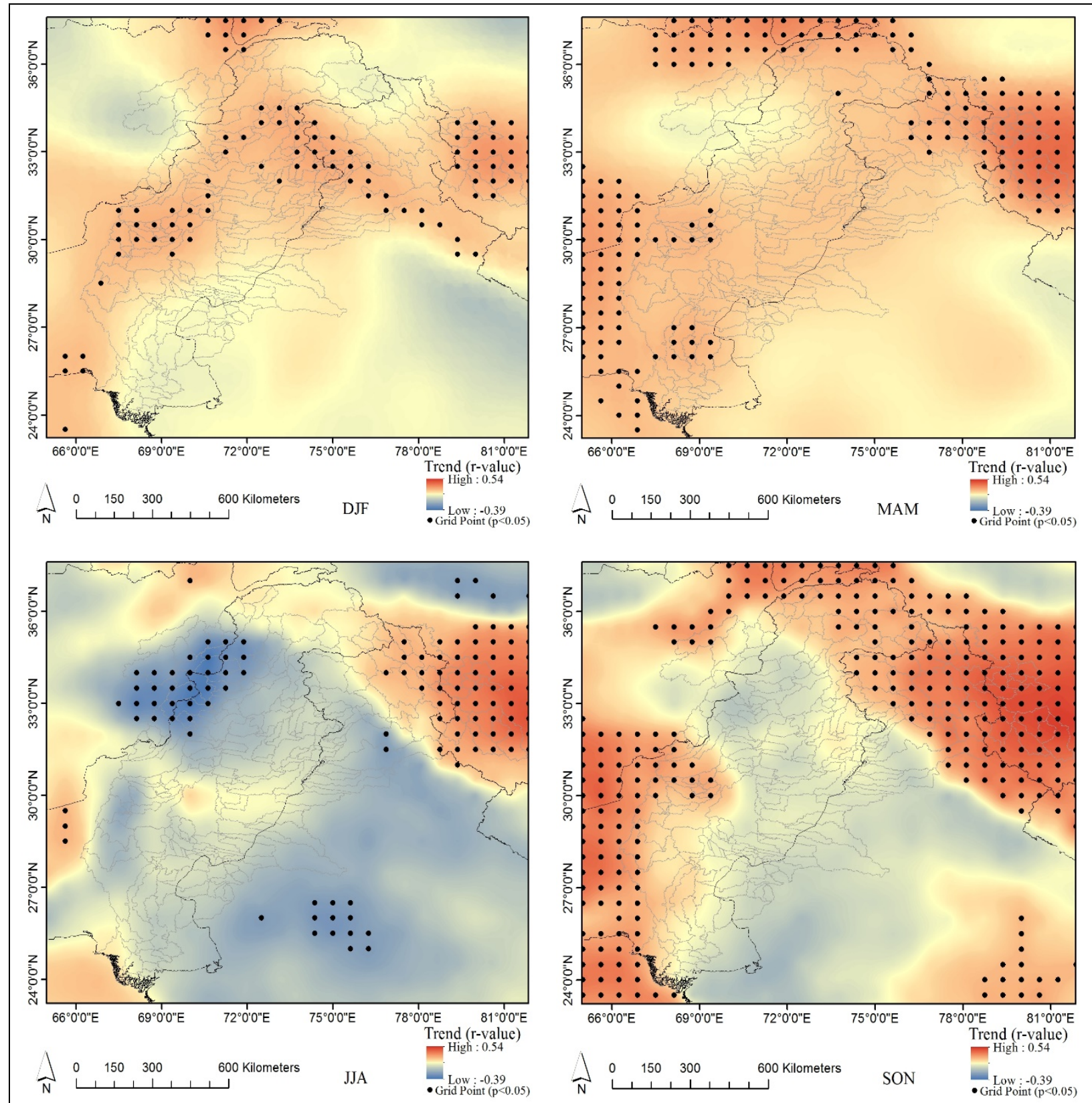

Figure 24. Spatial trend map of seasonal air temperature at $10 \mathrm{~m}$ 


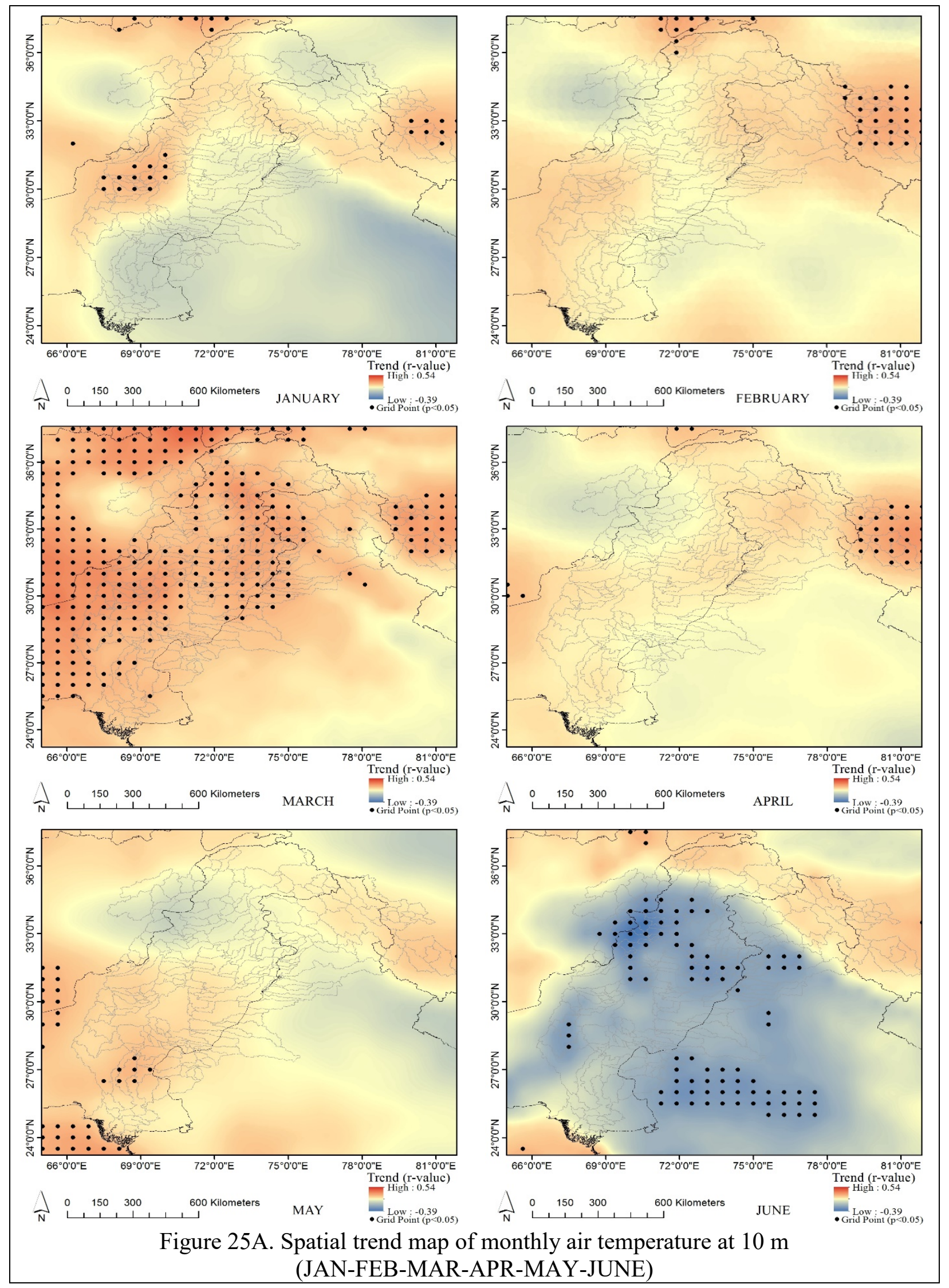




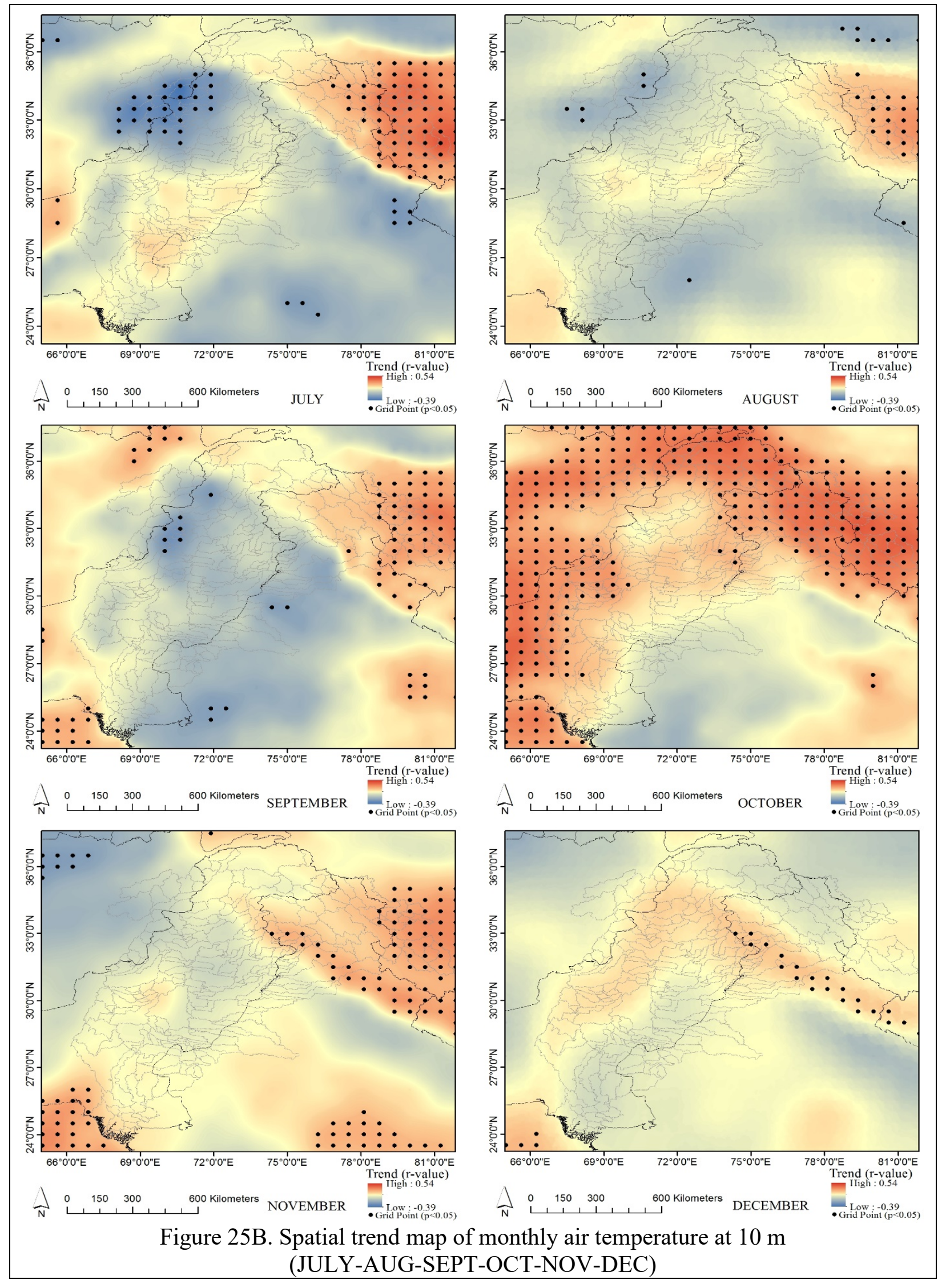

